\title{
Multifunctional photodynamic/ photothermal nano-agents for the treatment of oral leukoplakia
}

Lin Lin ${ }^{1,4+}$, Chuanhui Song ${ }^{2,4,5+}$ (B), Zheng Wei ${ }^{4,6}$, Huihui Zou ${ }^{2,4}$, Shengwei Han², Zichen Cao ${ }^{2,4}$, Xinyu Zhang ${ }^{2,4}$, Guorong Zhang ${ }^{4}$, Jianchuan Ran ${ }^{2,4}, \mathrm{Yu} \mathrm{Cai}^{3^{*}}$ and Wei Han ${ }^{2^{*}}$

\begin{abstract}
Oral leukoplakia (OLK) has gained extensive attention because of the potential risk for malignant transformation. Photosensitizers (PSs) played an indispensable role in the photodynamic therapy (PDT) of OLK, but the poor light sensitivity greatly hampered its clinical application. Herein, a novel organic photosensitive ITIC-Th nanoparticles (ITICTh NPs) were developed for OLK photodynamic/photothermal therapy (PTT). ITIC-Th NPs present both high photothermal conversion efficiency ( 38\%) and suitable reactive oxygen species (ROS) generation ability under $660 \mathrm{~nm}$ laser irradiation, making them possess excellent PDT and PTT capability. In 4-nitroquinoline 1-oxide (4NQO)-induced oral precancerous animal models, ITIC-Th NPs effectively suppress the OLK's cancerization without apparent topical or systemic toxicity in vivo. This study offers a promising therapeutic strategy for PDT and PTT in OLK treatment, and this study is the first interdisciplinary research in the field of multimodal therapy for OLK.
\end{abstract}

Keywords: Nanomedicine, Photodynamic therapy, Oral leukoplakia, Tumor

\footnotetext{
*Correspondence: iamycai@163.com; doctorhanwei@hotmail.com

${ }^{\dagger}$ Lin Lin and Chuanhui Song contributed equally to this work

${ }^{2}$ Department of Oral and Maxillofacial Surgery, Nanjing Stomatological Hospital, Medical School of Nanjing University, No 30 Zhongyang Road, Nanjing 210008, China

${ }^{3}$ Center for Rehabilitation Medicine, Rehabilitation \& Sports Medicine Research Institute of Zhejiang Province, Department of Rehabilitation Medicine, Zhejiang Provincial People's Hospital (Affiliated People's Hospital, Hangzhou Medical College), Hangzhou 310014, Zhejiang, China

Full list of author information is available at the end of the article
} permits use, sharing, adaptation, distribution and reproduction in any medium or format, as long as you give appropriate credit to the original author(s) and the source, provide a link to the Creative Commons licence, and indicate if changes were made. The images or other third party material in this article are included in the article's Creative Commons licence, unless indicated otherwise in a credit line to the material. If material is not included in the article's Creative Commons licence and your intended use is not permitted by statutory regulation or exceeds the permitted use, you will need to obtain permission directly from the copyright holder. To view a copy of this licence, visit http://creativecommons.org/licenses/by/4.0/. The Creative Commons Public Domain Dedication waiver (http://creativeco mmons.org/publicdomain/zero/1.0/) applies to the data made available in this article, unless otherwise stated in a credit line to the data. 


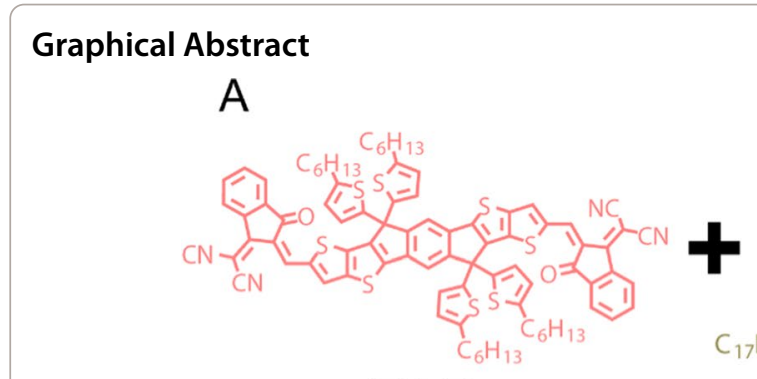

ITIC-Th

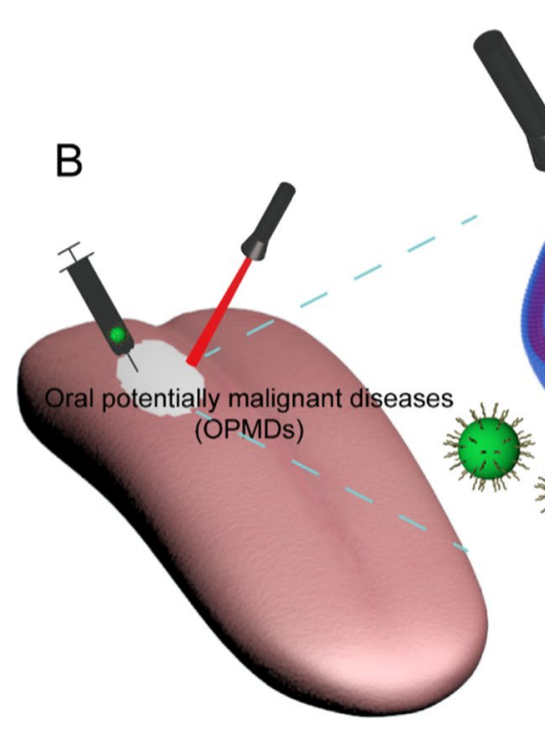

(a)The synthesis of ITIC-Th NPs. (b) The synergistic PDT/PTT in vivo.

\section{Introduction}

Oral squamous cell carcinoma (OSCC) accounts for more than $90 \%$ of oral malignancies, and most OSCC develops from oral precancerous lesions, which are collectively referred to as potentially malignant disorders (OPMDs) $[1,2]$. According to the definition of the World Health Organization (WHO), oral leukoplakia (OLK) is one of the most common OPMDs in oral mucosa, which is now defined as white irreversible and non-scratchable plaques that are at risk of turning into cancer $[3,4]$. To date, the prevalence rate of OLK is $3.5 \%$ (range: $0.13-$ $34.0 \%$ ), among which $4-13 \%$ could be transformed into malignant disease $[5,6]$. The presence and grading of epithelial dysplasia are the most commonly used prognostic factors to predict malignant transformation, which might be significantly reduced but not eliminated after the excision. Thus, OLK is an excellent clinical model for examining cancer prevention strategies [7-9].
Photodynamic therapy (PDT), as a minimally invasive approach, plays an indispensable role in the management of OLK. Unlike surgical resection, PDT is highly selective and repeatable with minimal scarring and is particularly valuable in regions with underlying functional structures [10, 11]. 5-aminolevulinic acid (5-ALA) is a water-soluble photosensitizer widely used to treat OPMDs, especially OLK. It can be administered intravenously, orally, or locally [12]. It is a precursor of porphyrins, which can't produce reactive oxygen species (ROS) by itself. After exogenous 5-ALA enters cells, it converts to porphyrin IX (PpIX) through the porphyrin-haem pathway, ROS generated once the PpIX is exposed to visible light (including 400-410 $\mathrm{nm}$ and $635 \pm 5 \mathrm{~nm}$ ) [13]. Moreover, 5-ALA-based PDT should be administered every 2-3 weeks, and repeated treatment is usually required to achieve desired results. Significantly, the treated areas should be strictly protected from light for $48 \mathrm{~h}$ after PDT, 


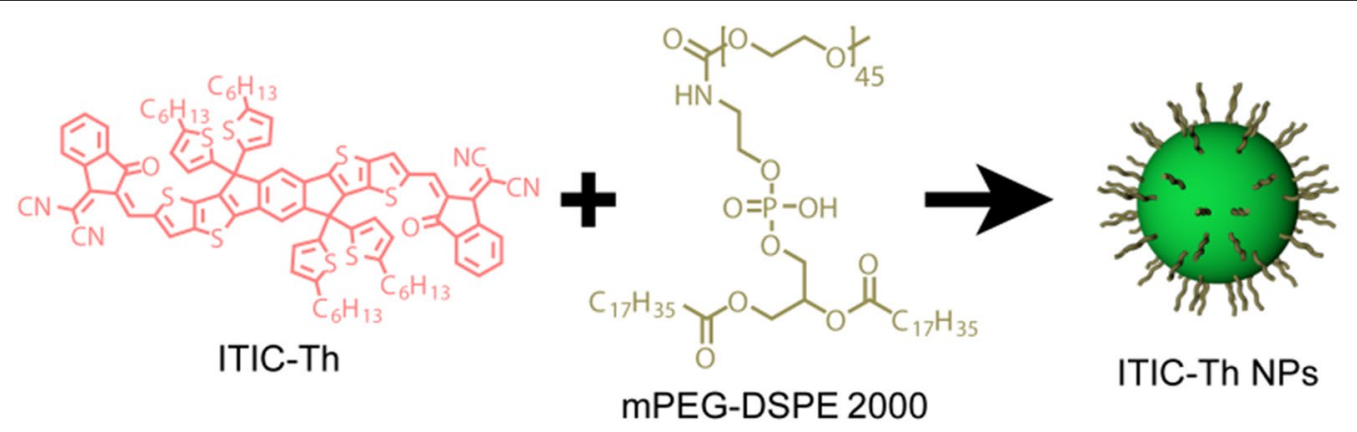

Fig. 1 The illustration of the synthesis of ITIC-Th NPS

and this exposure prophylaxis would continue throughout the entire treatment. Once inadvertently exposed to sunlight or even indoor light, papules, macules, blisters, or erosion may occur in the PDT-treated areas [14]. In addition, after the treatment, the lesions need to be protected from saliva for more than $3 \mathrm{~h}$ with thick gauze, which would restrict the patients' movement to a great extent $[15,16]$. According to the literature, the recurrence rate of 5-ALA-based PDT is as high as $60 \%[14,17$, 18]. Therefore, more efficient and fewer side effect photosensitizers should be developed to better study the PDT treated OLK.

The increasing cross-research between biomedicine and nanoscience provides more opportunities to develop new photosensitive materials for clinical treatment [19, 20]. Near-infrared (NIR) phototherapy has been widely applied for biomedicine due to its deep tissue penetration, robust anti-tumor efficacy, lower drug resistance, high specificity, and minimal invasiveness [21, 22]. In particular, photothermal therapy (PTT) is the other phototherapeutic method, which refers to light radiation and systemic local spot hyperthermia to heat the disaffected cells locally [23]. PTT can cause protein denaturation and cell membrane rupture, leading to irreversible damage to the target lesions [23-25]. To conquer the limitations of 5-ALA-based PDT, integrating PDT/PTT into OLK can block the cancerization process, promote the extinction of OLK lesions, and truly achieve precision medicine.

Herein, a novel acceptor-donor-acceptor (A-DA) organic photosensitive nano-agents based on 3,9-bis (2-methylene-(3-(1,1-dicyanomethylene)indanone) ) -5,5,11,11-tetrakis-(5-hexylthienyl) dithieno[2,3-d:2',3'-d']-s-indaceno[1,2-b:5,6-b']dithiophene (ITIC-Th) is designed for PDT/PTT. ITIC-Th is an efficient fused-ring electron acceptor with an alkyl thiophene group chain, making excellent NIR absorption and emission [26, 27]. By nanoprecipitation, we successfully prepared ITIC-Th nanoparticles (NPs) with a J-aggregative state, which present the advantages of redshift absorption, water solution, nontoxicity, and biodegradation ability. ITIC-Th NPs possess high photothermal conversion efficiency $(\sim 38 \%)$ and high ROS generation ability, endowing them with phototherapy both in vitro and in vivo. After studying the optical properties in vitro, we proved the local and system biosafety and excellent phototherapeutic efficacy. Furthermore, we successfully established a dynamic precancerous animal model similar to humans in pathogenesis, pathological changes, host immune activity, and molecular level. The in vivo study demonstrated that the malignant transformation could be effectively blocked through phototherapy. In this study, the multifunctional organic nano-agents were applied in the PDT/PTT treatment of OLK for the first time, and the established treatment mode was much close to the real clinical practice, which has a broad application prospect in treating oral precancerous lesions.

\section{Methods}

\section{Materials}

ITIC-Th was purchased from Derthon (Shenzhen, China). Tetrahydrofuran (THF) and dichloromethane were purchased from Admas-Beta (Shanghai, China). DSPE-mPEG 2000 was purchased from ToYongBio Tech (Shanghai, China). Leuk-1 was kindly provided by Professor Li Mao of the University of Maryland Dental School (Baltimore, USA). CAL 27 and $\mathrm{HaCaT}$ cell lines were get from the American Type Culture Collection (ATCC; Manassas, VA, USA). Singlet Oxygen Sensor Green (SOSG) kit was from Invitrogen (Thermo Fisher Scientific, USA). 1, 3-diphenylisobenzofuran (DPBF) and 4-nitroquinoline 1-oxide (4NQO) were purchased from Sigma-Aldrich (Saint Louis, USA). Cell Counting Kit-8 (CCK-8) was purchased from Bimake (Shanghai, China). ROS assay kit and DAPI were obtained from Beyotime (Shanghai, China). Cyclin D1 Monoclonal Antibody, p53 Monoclonal Antibody, Aldehyde dehydrogenase isoform 1 (ALDH1) Polyclonal Antibody, Programmed cell death 5 (PDCD5) Polyclonal antibody, and $\beta$-Actin Monoclonal Antibody were purchased from Proteintech (Wuhan, 
China). The anti-podoplanin (PDPN) antibody was purchased from Abcam (Shanghai, China). 5-ALA was purchased from FUDAN-ZHANGJIANG (Shanghai, China). Paraformaldehyde was from BOSTER (Wuhan, China). The Super -maxvision mouse/rabbit universal HRP Kit was from Typing Biotech (Nanjing, China).

\section{Synthesis of ITIC-Th NPs}

Referring to the previous literature, ITIC-Th NPs were synthesized by the reprecipitation method [28]. Briefly, under ultrasonic oscillation, $2 \mathrm{~mL}$ of ITIC-Th solution $(250 \mu \mathrm{g} / \mathrm{mL}$, THF) was dripped into the vigorously stirred DSPE-mPEG 2000 solution $\left(1 \mathrm{mg} / \mathrm{mL}, \mathrm{ddH}_{2} \mathrm{O}\right)$ slowly (Fig. 1). After the solution was clear and transparent, THF organic solvent was removed and purified by rotary evaporation to obtain water-soluble ITIC-Th NPs.

\section{Characterization of ITIC-Th NPs}

The ITIC-Th NPs morphology was observed on a transmission electron microscope (TEM, Hitachi H-7600, Japan), and the hydrodynamic diameter was measured by a dynamic light scattering system (DLS, BT-90). The UV - vis spectrum was obtained by an UV - vis - NIR spectrophotometer (PerkinElmer LAMBDA 750), and the fluorescence spectrum was acquired by a photoluminescence spectrometer (FLS980, Edinburgh Instruments, UK). A NIR fluorescence camera detected the NIR fluorescence imaging. Different thickness beef covered NPs solutions were used

$$
\varphi(\text { unkown })=\varphi \Delta(\text { ref })\left[\frac{k(\text { unkown })}{k(\text { ref })}\right]\left[\frac{F(\text { ref })}{F(\text { unkown })}\right]\left[\frac{P F(\text { ref })}{P F(\text { unkown })}\right]
$$

to check the fluorescence penetration of NPs.

\section{Photothermal performance of ITIC-Th NPs}

The photothermal performance of ITIC-Th NPs solution was measured through recording the solution $(0$, $6.5,12.5,25.0$, and $50.0 \mu \mathrm{g} / \mathrm{mL}$ ) temperature change with $660 \mathrm{~nm}$ laser irradiation $\left(0.4,0.6,0.8,1.0\right.$, and $\left.1.2 \mathrm{~W} / \mathrm{cm}^{2}\right)$ by an IR-thermal camera (FLIR, Arlington, VA, E50), while PBS was used as control. The photothermal conversion efficiency $(\eta)$ of ITIC-Th NPs was calculated by the Formula (1) [29]

$$
\eta=\frac{h A\left(T_{M}-T_{S}\right)-Q_{D i S}}{I\left(1-10^{-A 660}\right)}
$$

where $h$ is the heat transfer coefficient, A represents the container surface area, $T_{M}$ is the maximum temperature, $T_{S}$ means the ambient temperature. $Q_{D i s}$ is the heat dissipation, the I is the incident laser power, and A660 is the absorbance of the sample at $660 \mathrm{~nm}$. The $h \mathrm{~A}$ can be calculated from Formula (2)

$$
\tau_{s}=\frac{m_{D} c_{D}}{h A}
$$

where $\tau_{s}$ is the time constant for heat transfer of the system, calculated from Additional file 1: Fig S1; $\mathrm{m}_{\mathrm{D}}$ and $C_{D}$ are the mass and heat capacity, respectively, of the water. $\mathrm{Q}_{\text {Dis }}$ represents the heat dissipation from the light absorbed by the water and the quartz sample cell, so $\mathrm{Q}_{\text {Dis }}$ was calculated according to Formula (3)

where $T_{M \text { (water) }}$ is the maximum water temperature under laser irradiation.

\section{Photodynamic performance of ITIC-Th NPs}

The fluorescent probe SOSG and DPBF measured the generation of ${ }^{1} \mathrm{O}_{2}$. ITIC-Th NPs $\left(25 \mu \mathrm{g} / \mathrm{mL}, \mathrm{ddH}_{2} \mathrm{O}\right)$ were mixed with SOSG solution and irradiated by a $660 \mathrm{~nm}$ laser $\left(1.0 \mathrm{~W} / \mathrm{cm}^{2}\right)$ over $10 \mathrm{~min}$. The fluorescence spectrum of oxidized SOSG (excitation/emission: $488 / 525 \mathrm{~nm}$ ) was recorded by a UV vis NIR spectrophotometer every $10 \mathrm{~s}$. ITIC-Th NPs $(25 \mu \mathrm{g} / \mathrm{mL}$, dichloromethane) and DPBF $(2 \mu \mathrm{M})$ were dissolved into THF, then the solution was followed by irradiation $(660 \mathrm{~nm}$, $\left.1.0 \mathrm{~W} / \mathrm{cm}^{2}\right)$, then immediately detected the UV-Vis absorption. The ${ }^{1} \mathrm{O}_{2}$ quantum yield was evaluated by previous literature using Formula (2) [28].

$$
Q_{\text {Dis }}=\frac{c_{D} c_{D}\left(T_{M(\text { water })}-T_{S}\right)}{\tau_{s(\text { water })}}
$$

where unkown and ref are the 'ITIC-Th NPs' and 'MB', respectively. Quantum yields of singlet oxygen measured upon irradiation at $\mathrm{MB}$ as reference took into account as $0.52 \mathrm{k}$ is the slope of the difference in change in absorbance of DPBF with the irradiation time. $F$ is the absorption correction factor given by $\mathrm{F}=1-10^{-\mathrm{OD}}$ ( $\mathrm{OD}$ at the irradiation wavelength), and $\mathrm{PF}$ is the laser power.

\section{Cell culture}

Leuk-1, a premalignant leukoplakia cell line, was cultured in a defined keratinocyte serum-free medium (K-SFM; GIBCO, Invitrogen, Grand Island, USA). The OSCC cell line CAL 27 and human immortalized keratinocyte line $(\mathrm{HaCaT})$ were cultured in a complete Dulbecco's modified Eagle's medium (DMEM, Key GEN Bio TECH, China) medium with $10 \%$ Fetal Bovine Serum (FBS, BI, Israel). These cells were cultured in an incubator at $37^{\circ} \mathrm{C}$ with $5 \% \mathrm{CO}_{2}$. 


\section{Cell cytotoxicity assay}

The CCK- 8 assay detected the cytotoxicity of ITICTh NPs in Leuk-1 cells. Leuk-1 cells were seeded into a 96-well plate with different concentrations of ITIC-Th NPs and incubated for $24 \mathrm{~h}$, then some of them were exposed to $660 \mathrm{~nm}$ laser $\left(1.0 \mathrm{~W} / \mathrm{cm}^{2}\right)$ irradiation. Afterward, a CCK- 8 assay was used to detect the cell viability of different groups. Another group of Leuk-1 cells was seeded in six-well plates and incubated overnight. The medium was replaced with fresh K-SFM containing ITIC-Th NPs or not. After another incubation for $12 \mathrm{~h}$, cells were exposed to a $660 \mathrm{~nm}$ laser, and the cells were washed with PBS three times. Calcein-AM/PI Double Staining Kit labeled live cells in green and dead cells in red under the confocal microscope.

\section{Detection of intracellular ROS}

Intracellular ROS level was detected using the ROS Assay Kit. $1 \times 10^{6}$ Leuk- 1 cells were planted into a $35 \mathrm{~mm}$ glass-bottomed dish overnight. The attachable cells were cocultured with ITIC-Th NPs for another $4 \mathrm{~h}$, after washing with PBS, 2, 7-dichlorodi-hydrofluorescein diacetate (DCFH-DA) probe with the K-SFM medium at 1: 1000 was added to the dishes and incubated for $20 \mathrm{~min}$, followed by $660 \mathrm{~nm}$ laser irradiation $\left(1.0 \mathrm{~W} / \mathrm{cm}^{2}\right)$. Fluorescence was detected by the Nikon Digital Eclipse A1 Plus microscope.

\section{Western blot analysis}

Proteins were extracted from the $\mathrm{HaCaT} / \mathrm{CAL} 27$ / Leuk-1 cell. The primary antibodies used were p53, PDPN, ALDH1, Cyclin D1, and PDCD5. $\beta$-actin was used as the loading control. Protein levels were quantified using Image-Pro Plus and normalized to the $\beta$-actin level by densitometry.

\section{Patients}

Ten patients undergoing surgical treatment for oral leukoplakia in the Department of Oral and Maxillofacial Surgery, Nanjing Stomatological Hospital (Jiangsu, China), from January 2018 to December 2019 were recruited to our study, half of them had epithelial dysplasia and the other half did not. Oral leukoplakia was clinically diagnosed and confirmed using histology. The specific clinical features are shown in Table S1. Informed consent was obtained from each patient. This study was approved by the Nanjing Stomatological Hospital Ethics Committee (Application Permit Number: 2019NL-029(KS)).

\section{Immunohistochemical staining and score}

Immunohistochemistry was carried out according to the manufacturer's protocols. All immunostained sections were independently assessed and scored by two experienced pathologists using Imagescope software (Scanscope, USA) for quantitative analysis of images based on the visual evaluation. The related protein was quantified by visual grading according to the degree of staining: 0 (<5\%), 1 (6-25\%), 2 (26-50\%), 3 (51\%-75\%), 4 $(>75 \%)$, staining strength: 0 (no staining), 1 (weak staining), 2 (medium staining), 3 (strong staining). The scores were multiplied according to the intensity and degree of staining to obtain the final immune response score.

\section{Establishment of oral leukoplakia model in rats}

A total of 28 female-specific pathogen-free SpragueDawley (SD) rats, six to eight weeks of age, were purchased from Beijing Vitalstar Biotechnology Co.,Ltd. All animal experiments were followed by the guidelines international and national approved by the Nanjing Stomatological Hospital Ethics Committee (Application Permit Number: 2019NL-029(KS)). After a week of acclimation, 26 rats were treated with $75 \mu \mathrm{g} / \mathrm{ml} 4 \mathrm{NQO}$ dissolved in propylene glycol in the drinking water, and the remaining two rats were treated with normal drinking water. One rat was sacrificed in the 8th and 12th weeks, respectively. The tongue was excised, cut longitudinally, and fixed with $10 \%$ buffer formaldehyde for $48 \mathrm{~h}$. According to the manufacturer's protocols, the tissues were then paraffin-embedded, sectioned at $4 \mu \mathrm{m}$, and stained with hematoxylin and eosin (H\&E). In the $16^{\text {th }}$ week, two $4 \mathrm{NQO}$ rats and two normal drinking rats were sacrificed to evaluate the progress of oral leukoplakia and the biosafety of $4 \mathrm{NQO}$. The tongue, heart, liver, spleen, lung, and kidney were resected to perform histopathological analysis. The induction lasted for 16 weeks, with all rats drunk as needed and switched to purified water at week 17.

\section{Thermal imaging}

Finally, twenty rats with typical white patches on the back of the tongue were selected and randomly separated into five groups ( $\mathrm{n}=4$ per group, blank control, PBS/ ALA with laser irradiation, ITIC-Th NPs with or without laser irradiation). The remaining two rats were excluded because of atypical leukoplakia or inappropriate location. The rats were anesthetized by $2 \%$ isoflurane inhalation, after complete sedation, a mouth gag was applied to open their mouth and take out their tongues. The first group received no injections, while Group 2 was intralesional injection with $100 \mu \mathrm{l}$ PBS, Group 3 with $100 \mu \mathrm{l}$ freshly prepared 20\% 5-ALA, and Group 4/5 with the same dose of $100 \mu \mathrm{g} / \mathrm{ml}$ ITIC-Th NPs. Injections made from the marginal base of the target area and the scope should exceed 3-5 $\mathrm{mm}$ beyond the edge of the intended treatment site. In Group 1/2/5, the thermal imaging was measured by an infrared camera (FLIR, C3) at different 
A
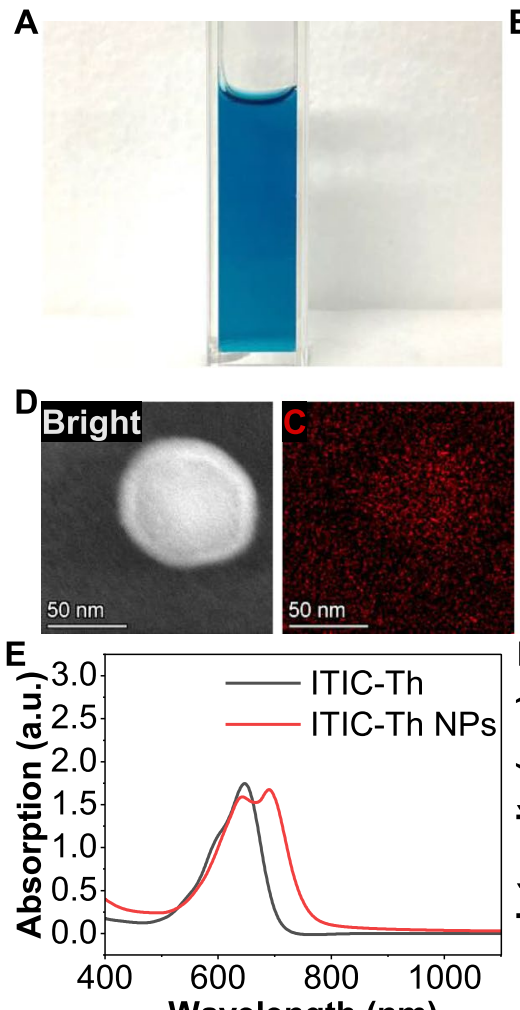

Havelength $(\mathbf{n m})$

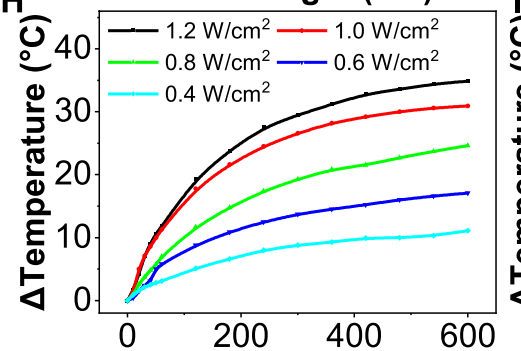

K

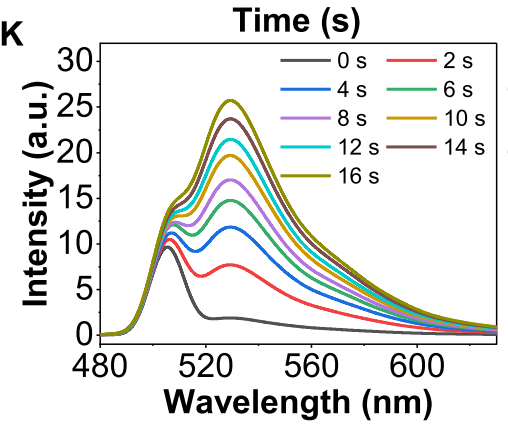

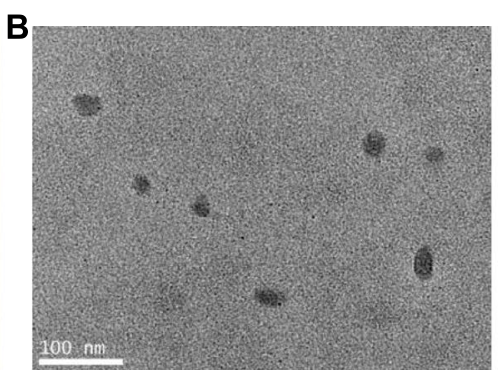
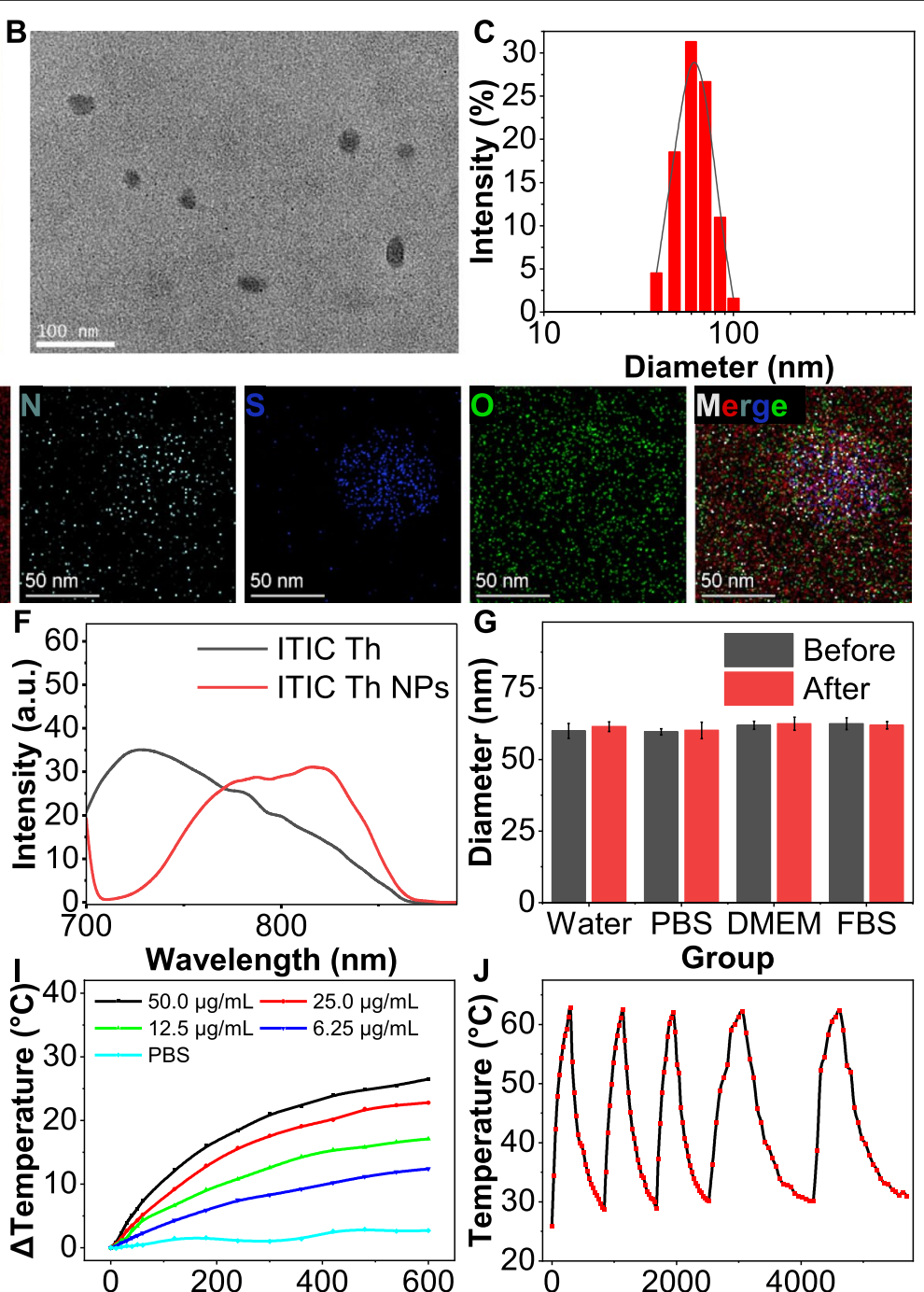

L

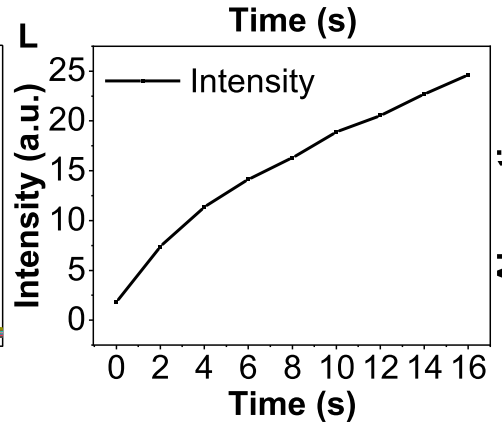

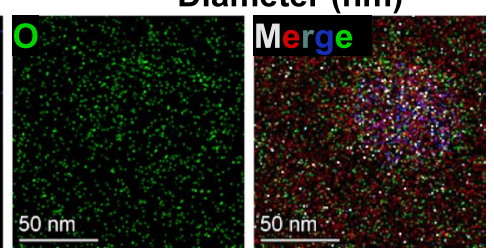
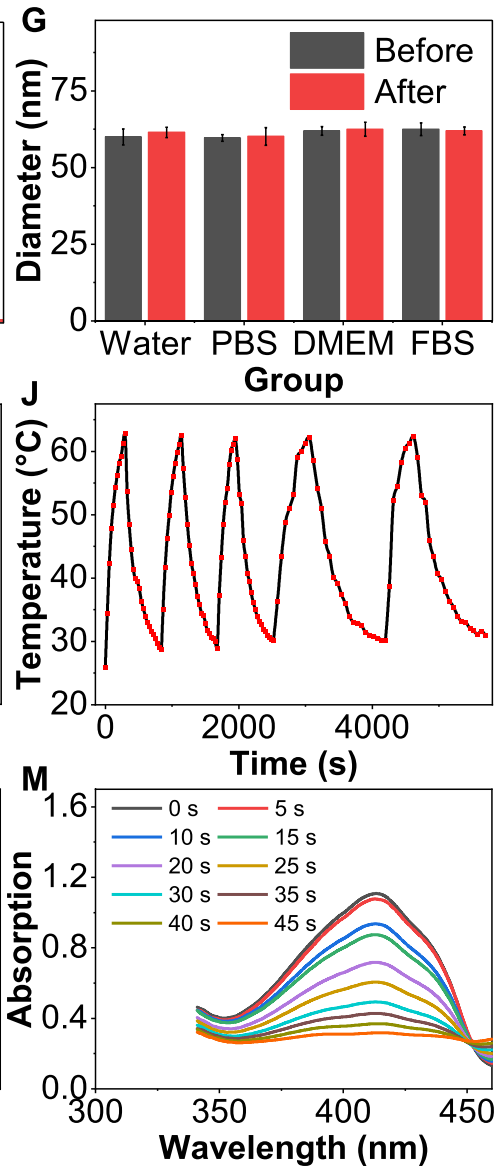

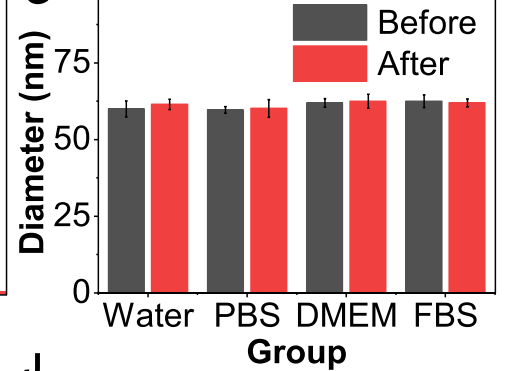

Fig. 2 The characterization of ITIC-Th NPS. A Optical image of the ITIC-Th NPs water solution in a cuvette. B The TEM image of ITIC-Th NPS in water solution. Scale bar $=100 \mathrm{~nm}$. C The DLS profiles of ITIC-Th NPs in water $(10 \mu \mathrm{g} / \mathrm{mL})$. The average diameters of ITIC-Th NPs were approximately $60 \mathrm{~nm}$, consistent with the TEM result. D The corresponding energy-dispersive spectroscopy (EDS) results of ITIC-Th NPs (The corresponding elements were marked in different colors in the image). E UV absorbance spectrum of ITIC-Th and ITIC-Th NPs ( $20 \mu \mathrm{g} / \mathrm{mL})$ solution. F The fluorescence emission spectrum of ITIC-Th and ITIC-Th NPs under emission of $660 \mathrm{~nm}$. G The average diameter of ITIC-Th NPs in corresponding solutions (water, PBS, DMEM, and FBS) after 2 weeks. H Photothermal profiles of ITIC-Th NPS in PBS under different power density irradiation $(660 \mathrm{~nm}, 0.4,0.6,0.8,1.0$, and $\left.1.2 \mathrm{~W} / \mathrm{cm}^{2}\right)$. I Photothermal profiles of ITIC-Th NPs in PBS with different concentrations $(6.25,12.5,25.0$, and $50.0 \mu \mathrm{gg} / \mathrm{mL})$ under laser irradiation $\left(660 \mathrm{~nm}, 1 \mathrm{~W} / \mathrm{cm}^{2}\right)$. JThe heating curve of the ITIC-Th NPs in PBS during 5 cycles of on-and-off laser irradiation $\left(660 \mathrm{~nm}, 1 \mathrm{~W} / \mathrm{cm}^{2}\right)$. K Fluorescence spectra of ITIC-Th $(20 \mathrm{\mu g} / \mathrm{mL})$ mixed with SOSG $\left(10^{-5} \mathrm{~mol} / \mathrm{L}\right)$ upon laser irradiation $\left(660 \mathrm{~nm}, 1 \mathrm{~W} / \mathrm{cm}^{2}\right)$ with various duration. L Fluorescence intensity was measured at different time intervals. $M$ Absorption spectra of ITIC-Th $(20 \mu \mathrm{g} / \mathrm{mL})$ mixed with DPBF $\left(6 \times 10^{-5} \mathrm{~mol} / \mathrm{L}\right)$ under laser irradiation $\left(660 \mathrm{~nm}, 1 \mathrm{~W} / \mathrm{cm}^{2}\right)$ with various durations 
time points following a $660 \mathrm{~nm}$ laser $\left(1 \mathrm{~W} / \mathrm{cm}^{2}\right)$ irradiation for $3 \mathrm{~min}$. While in the third group, a $365 \mathrm{~nm} \mathrm{UV}$ light was performed $3 \mathrm{~h}$ post-injection to test the illumination reaction. Afterward, a laser at the wavelength of $632 \mathrm{~nm}\left(0.5 \mathrm{~W} / \mathrm{cm}^{2}\right)$ was also irradiated for $3 \mathrm{~min}$. Therapies were conducted every five days and each rat received three treatments.

\section{Efficacy evaluation in vivo}

The therapeutic effect was evaluated and independently scored by two experienced oral mucosal clinicians. Four parameters were assessed for each subject, including size, type, color, and texture [30, 31]. If the lesions extended to two or more sites, the site with more severe lesions was selected as the target area for evaluation. The size of the oral leukoplakia was determined by measuring any clinically visible area of morphological change and calculated as 'length $\times$ width'. The same investigator made measurements before the treatment (Day 0) and after complete treatment (Day 14), respectively. Before treatment, all initial areas were recorded as 0 points. On day 14, compared with the previous period, the cross-sectional area of measurable leukoplakia decreased by $\geq 50 \%$ was recorded as negative 2 points, increased by $\geq 50 \%$ was recorded as 2 points, and the rest of them were labeled as 0 points. The types of lesions are mainly divided into three grades according to surface roughness, protuberance degree, ulcer or erosion: granular protuberance, verrucous protuberance, villous protuberance or prickly protuberance, which are significantly higher than the mucosal surface, or those with ulcers are marked as 3 points; Uneven and higher than the mucosal surface, the local ulcer was marked as 2 points; Homogeneous plaques slightly above the mucosal surface without ulceration were scored as 1 point. Color is divided into two grades, pure white is marked as 2 points, gray or light white is marked as 1 point. The texture is graded on three scales, with 3 for hard, 2 for medium, and 1 for soft. The total score was calculated by adding up all the scores. Cases that are clinically evaluated as cancerous are scored directly as 10 points. All operations were performed under anesthesia. Finally, all of the rats were euthanized on the 14th day, tongues were collected, and stained by H\&E.
Immunohistochemistry (ALDH1 and p53) was carried out according to the manufacturer's protocols.

\section{Chronic toxicity experiment}

The body weight was measured and recorded every 2 days. After rats were sacrificed, the tongues and their adjacent tissues, the major organs were gathered for histological analysis, and blood samples were collected for routine and biochemical examinations.

\section{Statistical analysis}

All analyses were carried out as indicated by GraphPad Prism 8.0. Mean and standard deviation was used as descriptive statistics. The student's $t$-test was used to calculate statistical differences between two groups, and one-way analysis of variance (ANOVA) was used to compare differences between more than two groups. The value of $\mathrm{p}<0.05$ was considered statistically significant.

\section{Results and discussion \\ Preparation and characterization}

ITIC-Th NPs were synthesized by the nanoprecipitation method reported in our previous literature [28, 32] and had a uniform and transparent appearance in an aqueous solution (Fig. 2A). TEM images of ITIC-Th NPs presented a diameter of approximately $50 \mathrm{~nm}$ with spherical-like morphology (Fig. 2B), in diameter in favor of cellular uptake [33]. DLS results indicated that the average size of ITIC-Th NPs was nearly $60 \mathrm{~nm}$, which was consistent with the TEM result (Fig. $2 \mathrm{C}$ ). The element mapping analysis also showed the corresponding element distribution in the NPs (Fig. 2D), where the carbon $(\mathrm{C})$, nitrogen $(\mathrm{N})$, sulfur $(\mathrm{S})$, and oxygen $(\mathrm{O})$ were marked as red, cyan, blue, and green, respectively, indicating the success of synthesizing. The UV-Vis spectrum of free ITIC-Th exhibited peaks at $646 \mathrm{~nm}$. When ITIC-Th NPs were formed, the peak showed a redshift to $692 \mathrm{~nm}$, which confirmed the presence of NPs (Fig. 2E). The fluorescence spectra of ITIC-Th NPs showed that the emission peak was $820 \mathrm{~nm}$ (Fig. 2F), indicating the fluorescence imaging ability in the near-infrared [34]. To test the stability of NPs, we checked the particles' size and appearance in different solutions for two weeks [35].

(See figure on next page.)

Fig. 3 In vitro therapeutic evaluation of ITIC-Th NPS. A Fluorescence images of ITIC-Th NPs with a different concentration in PBS (Excitation wavelength: $660 \mathrm{~nm}$ ). B Relationship between concentration of ITIC-Th and NIR fluorescence intensity. C CCK-8 evaluated the cell cytotoxicity assay. Leuk-1 cells were treated with various formulations for $24 \mathrm{~h}$. D The fluorescence of Live/Dead cells. Live and dead cells were signaled in green and red fluorescence, respectively. Scale bar $=100 \mu \mathrm{m}$. E Fluorescence photographs of cellular ROS generation treated with ITIC-Th NPS $(10 \mu \mathrm{g} / \mathrm{mL})$. Scale bar $=100 \mu \mathrm{m}$. F Representative immunoblots indicated different protein levels in CAL 27 from each treatment group, and the quantitative analysis was shown in G. H Representative immunoblots indicated different protein levels in Leuk-1 from each treatment group, and the quantitative analysis was shown in I $\left.{ }^{* *} p<0.01 ;{ }^{* *} p<0.001\right)$ 
The results showed that the as-prepared NPs had good stability (Fig. $2 \mathrm{G}$ and Fig S1A). Considering the microenvironment in OLK, we further checked the stability of NPs under different $\mathrm{pH}$ circumstances. The UV-VIS spectrum and DLS results showed a minimal difference between different $\mathrm{pH}$, indicating that the property of NPs can stay stable regardless of the environment (Additional file 1: Fig S1B, C). All those data suggested that the NPs were stable enough for therapy in vitro and in vivo.

\section{Photothermal and photodynamic properties}

The photothermal properties of the ITIC-Th NPs were evaluated by using a $660 \mathrm{~nm}$ laser as the excitation light. The photothermal effect of ITIC-Th NPs was positively correlated with the power density. The elevated temperature of ITIC-Th NPs $(100 \mu \mathrm{g} / \mathrm{mL})$ gradually increased from $11.1{ }^{\circ} \mathrm{C}$ to $34.9{ }^{\circ} \mathrm{C}$ at $10 \mathrm{~min}$ ' irradiation (the power density from 0.4 to $1.2 \mathrm{~W} / \mathrm{cm}^{2}$ ). Even at a low intensity of $0.8 \mathrm{~W} / \mathrm{cm}^{2}$, the solution temperature was still lifted by $24.7^{\circ} \mathrm{C}$ (Fig. 2H). The temperature variation curves of ITIC-Th NPs solutions were also positively correlated with concentration. Under continuous laser irradiation $\left(1.0 \mathrm{~W} / \mathrm{cm}^{2}\right)$, the temperature of ITIC-Th NPs $(50 \mu \mathrm{g} / \mathrm{mL})$ could increase by $26.5{ }^{\circ} \mathrm{C}$ at $10 \mathrm{~min}$, which demonstrated the excellent photothermal performance (Fig. 2I). The photothermal conversion efficiency $(\eta)$ [29] of ITICTh NPs was calculated to be nearly $38.6 \%$ (Additional file 1: Fig S2A, B). Subsequently, we further examined the photothermal stability of ITIC-Th NPs, which is vital towards a photosensor [36]. We found that the maximum photothermal temperature of ITIC-Th NPs barely changed after five reversible heating and cooling cycles (Fig. 2J). This result highlighted the excellent photothermal stability of ITIC-Th NPs, which was beneficial for PTT application in vivo. To determine the singlet oxygen $\left({ }^{1} \mathrm{O}_{2}\right)$ production of ITIC-Th NPs, the fluorescent probe SOSG and DPBF were utilized, respectively. The intensity of ITIC-Th NPs and SOSG solution drastically increased under laser irradiation at $525 \mathrm{~nm}\left(660 \mathrm{~nm}, 1.0 \mathrm{~W} / \mathrm{cm}^{2}\right)$, indicating the amount of singlet oxygen generation. The singlet oxygen production of ITIC-Th NPs was $6.82 \%$ (Fig. $2 \mathrm{~K}$ and L), which is close to that of free ICG $(7.7 \%)$ used in the clinic [37]. The ROS generation ability of ITIC-Th NPs was further measured by using DPBF as a probe [38]. Figure $2 \mathrm{M}$ indicated the excellent ROS generation ability of ITIC-Th NPs. An electron spin resonance (ESR) test was conducted to analyze ROS species, which showed that the superoxide radical is the major radical oxygen species (Additional file 1: Fig S2C). The research results mentioned above demonstrated superior photothermal and photodynamic properties. During the treatment, the PDT-inducing cell dying can lead to the related antigen releasing. The PTT can increase local blood flow, promoting tissue healing and immunerelated cells in vivo. Also, the cellular excessive ROS level could induce oxidative modification in other oxygen species, proteins, or lipids, even resulting in cellular damage and cell death [39], resulting in the relative cell markers alter.

\section{In vitro cytotoxicity}

The NIR imaging was used to determine the fluorescence imaging ability of ITIC-Th NPs. In vitro fluorescence imaging showed that pure PBS had no imaging capability, and the signal was generated with the addition of ITIC-Th NPs (Fig. 3A). Moreover, the fluorescence intensity increased with the increasing concentration and presented the brightest signal when the concentration reached $75 \mu \mathrm{g} / \mathrm{mL}$ compared to the background, proving that the ITIC-Th NPs had good imaging capability (Fig. 3B). Encouraged by the excellent fluorescence imaging property, we further tested the penetration ability of ITIC-Th NPs solution in NIR. Fluorescence imaging was used to detect penetration by covering different beef over the NPs solution. Even when the tissue thickness was increased to $4 \mathrm{~mm}$, the NIR imaging can clearly show the contour of the capillary, suggesting the excellent tissue penetration of NPs (Additional file 1: Fig S3). The cytotoxicity of ITIC-Th NPs towards Leuk-1 cells in vitro was confirmed by CCK- 8 assays in the presence or absence of $660 \mathrm{~nm}$ laser irradiation. Interestingly, ITIC-Th NPs were non-toxic to human keratinocytes HaCat and other normal cell lines (RAW 264.7 and THP-1) (Additional file 1: Fig S4A-C). Still, in premalignant leukoplakia cells, cell viability was suppressed dramatically under laser contrast to the no laser illumination group (Fig. $3 \mathrm{C}$ ). $\mathrm{IC}_{50}$ values were calculated using GraphPad Prism 8.0, compared with hematoporphyrin (Additional file 1: Fig S4D), ITICTh NPs $\left(\mathrm{IC}_{50}=10.36 \mu \mathrm{g} / \mathrm{mL}\right)$ showing a more apparent inhibitory effect on cell activity, implying the highly desirable PDT/PTT effect of ITIC-Th NPs, which was an effective method to avoid the potential drug side effects. Accordingly, $10 \mu \mathrm{g} / \mathrm{mL}$ was selected as the working concentration for subsequent experiments. To better analyze the cellular uptake of NPs, we used fluorescent PEG to visualize the particles in cells. The fluorescence showed the particles could distribute in the cells along the time (Additional file 1: Fig S5). The mechanism of cell death was further analyzed by FITC-Annexin V/ propidium iodide staining. ITIC-Th NPs were cultured in Leuk-1 cells at the concentration of $10 \mu \mathrm{g} / \mathrm{mL}$ with or without laser illumination $\left(660 \mathrm{~nm}, 1 \mathrm{~W} / \mathrm{cm}^{2}\right)$, and non-treated cells were taken as control. The results observed by confocal laser microscopy were shown in Fig. 3D. Live cells 

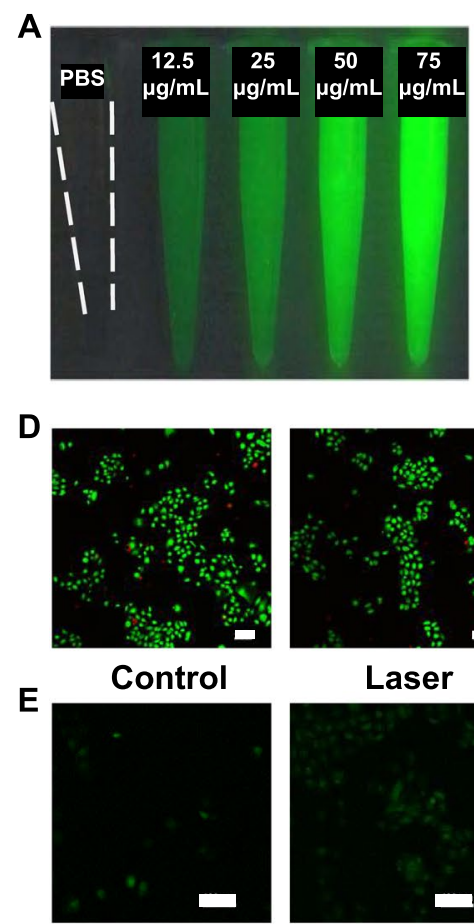

Control

F ALDH 1 - $-\infty$

p53 ए-

Cyclin D1 $-\infty-\infty-\infty$

PDPN $\quad-\infty \pi \infty$

PDCD5

$\beta$-actin

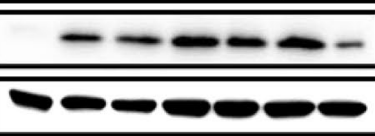

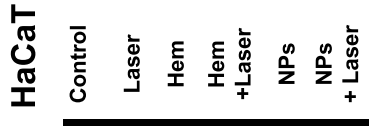

Leuk-1

H

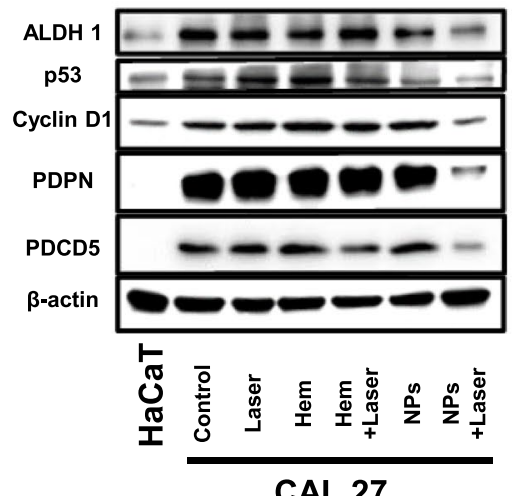

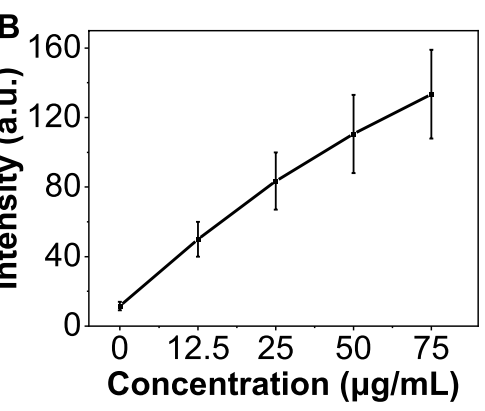
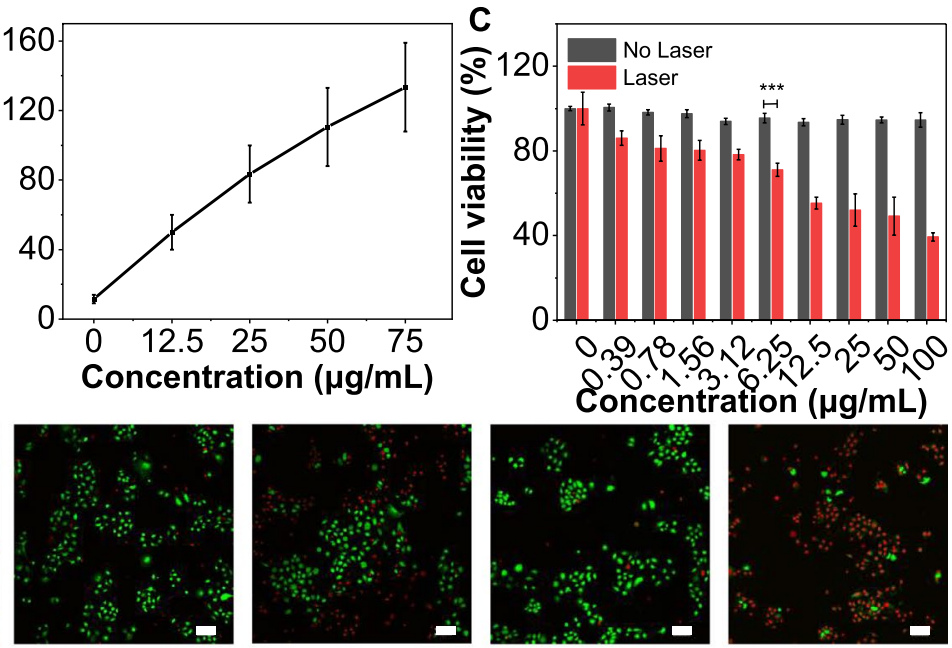

Hem

Hem + Laser

NPs

NPs + Laser
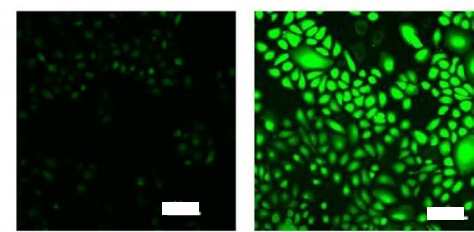

NPs + Laser
NPs

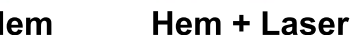

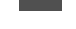

HaCat
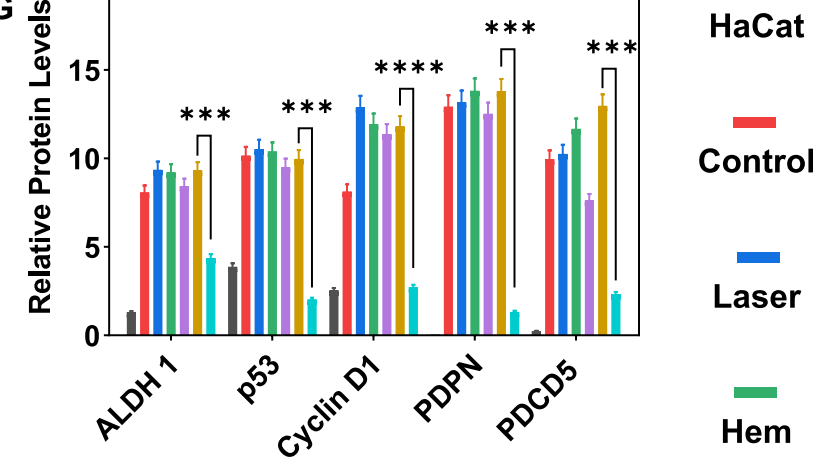

Hem

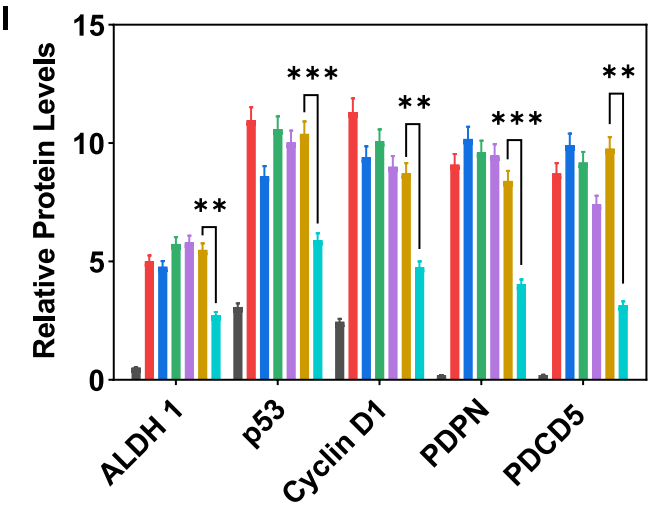

Hem+Laser

NPs NPs + Laser

Fig. 3 (See legend on previous page.) 
were stained with Calcein-AM to show a green fluorescence signal, while dead cells were stained with PI to show red fluorescence signal. The cells were green in control, NPs, hematoporphyrin (Hem), laser group, meaning that the cells were sound and the NPs were safe without laser irradiation. After laser illumination, the ratio of cells with red signal was increased dramatically in the NPs group, suggesting the effective killing rate compared with the Hem group. The quantitative analysis was demonstrated in Additional file 1: Fig S6A, which consists of fluorescent images. All these data showed that the NPs possessed excellent biocompatibility without laser application but had a better therapeutic effect under laser irradiation than hematoporphyrin.

\section{ITIC-Th NPs inhibited OLK carcinogenesis in vitro}

The generation of ROS plays a crucial role in treating OLK with PDT. Based on the efficient ROS generation ability in solution, we used the $2^{\prime}, 7^{\prime}$-dichlorofuorescin diacetate (DCFH-DA) probe to test the intracellular ROS generation in different groups and analyzed by CLSM and Image J [40]. DCFH-DA has no fluorescence, but it can

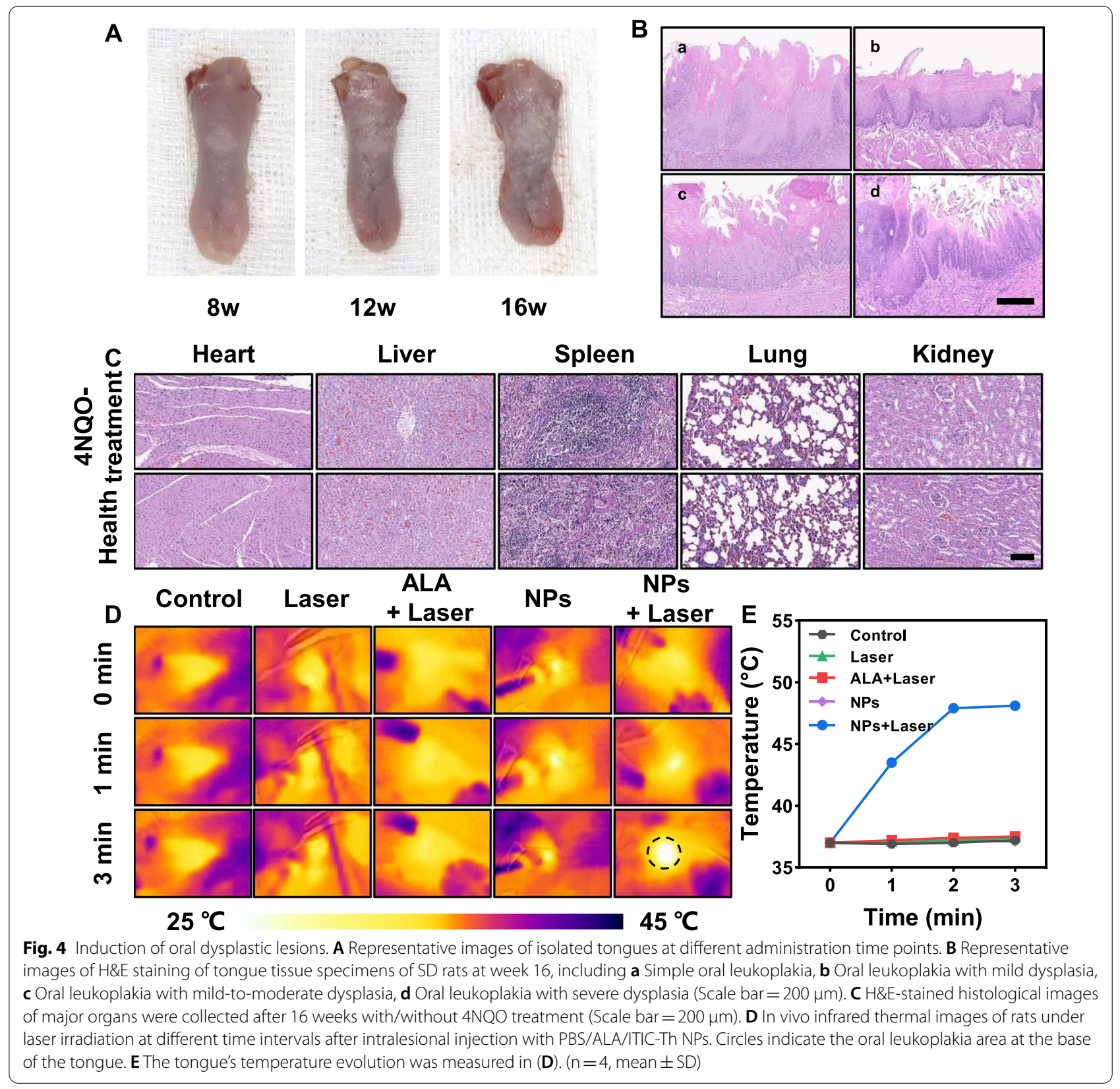


be rapidly converted into fluorescent 20, 70-dichlorofluorescein by ROS [41]. As shown in Fig. 3E, a strong green fluorescence could be observed in Leuk-1 cells incubated with ITIC-Th NPs after laser irradiation $(660 \mathrm{~nm}, 1 \mathrm{~W} /$ $\mathrm{cm}^{2}$ ). In contrast, negligible hematoporphyrin was emitted without ITIC-Th NPs or laser, suggesting the NPs produced much ROS after laser irradiation [42]. Furthermore, taking the hematoporphyrin with laser as a compared group, the green fluorescence is much more than that, indicating the effective ROS generation. The quantitative result in Additional file 1: Fig S6B further supported this conclusion $(\mathrm{P}<0.01)$. These results proved that ITIC-Th NPs promoted a remarkable PDT therapeutic effect.

As high intracellular ROS levels can induce cell damage and even death, we speculate this may change the relative markers. To date, some biological biomarkers have been reported of potential value in predicting malignant transformation of oral leukoplakia, such as ALDH1, p53, Cyclin D1, PDCD5, and PDPN [43-45]. ALDH1, an isomer of aldehyde dehydrogenase, has been demonstrated to be a tumor stem cell marker for various solid tumors, including OSCC, and can be used as a prognostic marker for head and neck squamous cell carcinoma (HNSCC) survival [46]. p53 was known as a tumor suppressor gene that induced cell apoptosis, necrosis, and autophagy under cell stress. The mutation and inactivation of p53 were crucial in developing OLK [47]. Cyclin D1, a regulator of Cyclin-dependent kinase (CDK), promotes cell cycle progression during the G1 phase, which played a key role in cell proliferation and growth regulation, mitochondrial activity modulation, DNA repair, and cell proliferation migration control [48]. PDCD5 can be involved in programmed cell death, cell cycle, embryonic development, and immune regulation. The expression rate of PDCD5 deletion was consistent with the positive expression rate of mutant p53 and was decreased in laryngeal squamous cell carcinoma but still unclear in OSCC [49, 50]. PDPN was a mucin-type transmembrane glycoprotein, and positive expression of ALDH1/p53/Cyclin D1/ PDPN was significantly associated with malignant transformation of OLK [51, 52]. As shown in Fig. 3F-I, the ALDH1/p53/ Cyclin D1/PDPN/PDCD5 protein expression levels significantly decreased after co-cultured with
ITIC-Th NPs and laser irradiation $\left(660 \mathrm{~nm}, 1 \mathrm{~W} / \mathrm{cm}^{2}\right)$. In particular, this phenomenon was more outstanding in the human tongue cancer cells than in the leukoplakia cells. These results indicated that ITIC-Th NPs could significantly down-regulate the expression of tumorrelated genes in vitro. Since these biomarkers were associated with the risk of OLK's malignant transformation, we speculated that with photothermal and photodynamic effects, ITIC-Th NPs may prevent oral precancerous lesions from transforming into OSCC, although the specific mechanism still needs further studies.

To further determine the meaning of relative protein in oral leukoplakia, we detected the expression levels of these biomarkers in oral leukoplakia tissues with different levels of epithelial dysplasia. A total of 10 OLK patients ( 3 males and 7 females, mean age $59.6 \pm 14.1$ years) were enrolled in the study. Five of them had epithelial dysplasia, and the remaining did not. Compared with simple hyperplastic tissues, the ALDH1/p53/Cyclin D1/ PDPN protein expression was more obvious in the tissues with epithelial dysplasia, which was significantly associated with malignant transformation of OLK. The role of PDCD5 in the development of OLK remains to be elucidated. In our research, PDCD5 expression was decreased with increasing histological grade, which was consistent with ovarian epithelial cancer findings, suggesting that it may also play an important role in OLK carcinogenesis (Additional file 1: Fig S7).

\section{Successful establishment of the oral leukoplakia rat model} $4 \mathrm{NQO}$ is an aromatic amine heterocyclic compound widely used as the most recognized chemical precursor carcinogen [14]. Research has certified that 4NQO establishes precancerous or cancerous models by causing intracellular oxidative stress, DNA adduction, mutagenesis, and tumor induction [53, 54]. 4NQO-induced precancerous model is a multi-stage dynamic and continuous process from normal oral mucosa to OLK until OSCC, and pathological stages underwent hyperplasia, dysplasia (mild, moderate, and severe), carcinoma in situ, and invasive SCC $[55,56]$. This model closely mimics the carcinogenesis of human oral dysplasia that is suitable for studying the specific cancerous process of OLK, especially in the development of biomarkers for

(See figure on next page.)

Fig. 5 ITIC-Th NPs therapy intercepts the cancerous progression of oral leukoplakia in 4NQO rats. A Manifestations of tongue lesions in rats on days 3, 8, and 14 after different treatments. B Representative histological images of H\&E, ALDH1, and p53 staining of collected tongue tissues. Scale bar $=200 \mu \mathrm{m}$. C Therapeutic effect scores of each group. According to lesion area, type, color, and texture, comprehensive judgment was made by two experienced oral mucosal clinicians. $(n=4$, mean $\pm S D)$. D The score of ALDH1 and p53 IHC stain in $B$. $\left(n=4\right.$, mean $\pm S D,{ }^{*} p<0.05$, $\left.{ }^{* * *} p<0.001\right)$. E H\&E-stained histological images of major tissues near the site of treatments. Scale bar $=200 \mu \mathrm{m}$. F Average body weight of different groups of rats. ( $n=4$, mean \pm SD). $\mathbf{G}$ H\&E-stained histological images of major organs after the different treatments. Scale bar $=200 \mu \mathrm{m}$. $\mathbf{H}-\mathbf{M}$ Serum biochemical study and hematology assay after the different treatments. $(n=4$, mean $\pm S D)$ 


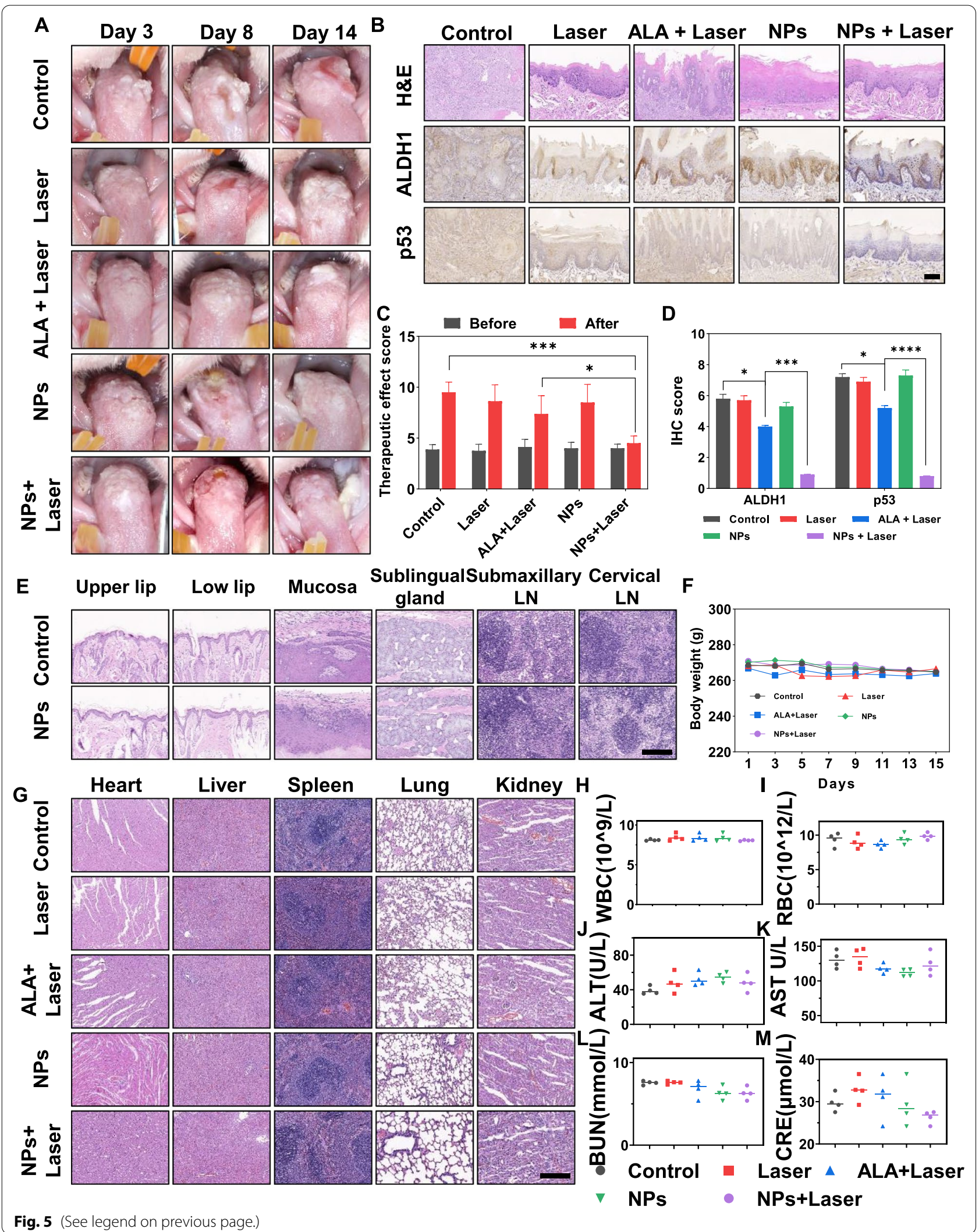


early diagnosis and epithelial cell transformation [55, 57]. After feeding at $75 \mu \mathrm{g} / \mathrm{ml}$ 4NQO drinking water, all rats were anesthetized by isoflurane inhalation at 8,12 , and 16 weeks [58]. Researchers pulled outward the tongues to observe the changes, the typical tissue was chosen for histopathological examination. In the 8th week, the tongues remained normal, while in the 12th week they started to turn white. From this point on, all of the rats gradually exhibited non-detachable white plaque, and typical lesions appeared at week 16 similar to human oral leukoplakia (Fig. 4A). 4NQO has been proved to induce cancer in many parts of the oral cavity, such as the dorsal tongue, ventral tongue, palate, and even esophagus [53]. Many studies have confirmed that tongue lesions occurred almost $100 \%$, especially on the dorsal mucosa. In our study, lesions localized mainly on the tongue dorsum with a few lesions on the palate or along the lateral borders of the tongue, which was consistent with the previous reports [53]. In the 16th week, we picked two $4 \mathrm{NQO}-$ treated rats at random and found varying degrees of pathological changes in tongue lesions, including simple oral leukoplakia and oral leukoplakia with mild, mildto-moderate, or severe epithelial dysplasia (Fig. 4B). Also, the two normal drinking rats were sacrificed. Figure $4 \mathrm{C}$ showed no significant difference in histopathological features of major organs between 4NQO-treated and healthy rats. All the results above indicated that we had successfully established the rat model of oral leukoplakia, and 4NQO did not cause significant damage to the main organs in rats, and the rats can be used for further in vivo experiments.
In vivo PTT/PDT of ITIC-Th NPs against oral leukoplakia

To explore the therapeutic effect of ITIC-Th NPs on oral leukoplakia in vivo and compared with the previous photosensitizer, we selected twenty rats with typical white plaque lesions on the dorsal surface of the tongue and randomly divided them into five groups $(\mathrm{n}=4)$ for PTT/ PDT. The rats received intralesional injections of $100 \mu \mathrm{g} /$ $\mathrm{ml}$ ITIC-Th NPs or 20\% 5-ALA and were irradiated with/ without 660/632 nm laser for $3 \mathrm{~min}$ [14]. In clinical practice, doctors often choose gauzes soaked with the photosensitizer solution to reduce needle insertion pain to place over the lesion, and patients should minimize oral activity. Since we could not keep the rats' tongues inactive for three hours, the intralesional injection was applied to reduce the influence of salivary secretion or tongue movement on ALA absorption. The schedule was shown in Additional file 1: Fig S8. Rats without drug injections were used as blank controls, and rats injected with PBS were used as negative controls. The efficient accumulation of particles in pathological tissues is the key to PDT/ PTT therapy. As the treatment schematic illustration is shown in Additional file 1: Fig. S8, local injection ensures direct access of NPs to the diseased tissue and local accumulation of solution after injection. A thermal monitor was used to observe the photothermal capacity of ITICTh NPs in vivo at different time points. The lesions' temperature of ITIC-Th NPs + laser group rapidly increased and reached about $48.1{ }^{\circ} \mathrm{C}$, suggesting the superior photothermal conversion of such ITIC-Th NPs. Pure ITIC-Th NPs did not heat up in the absence of light, and ALA had a photodynamic effect but no photothermal effect, so the

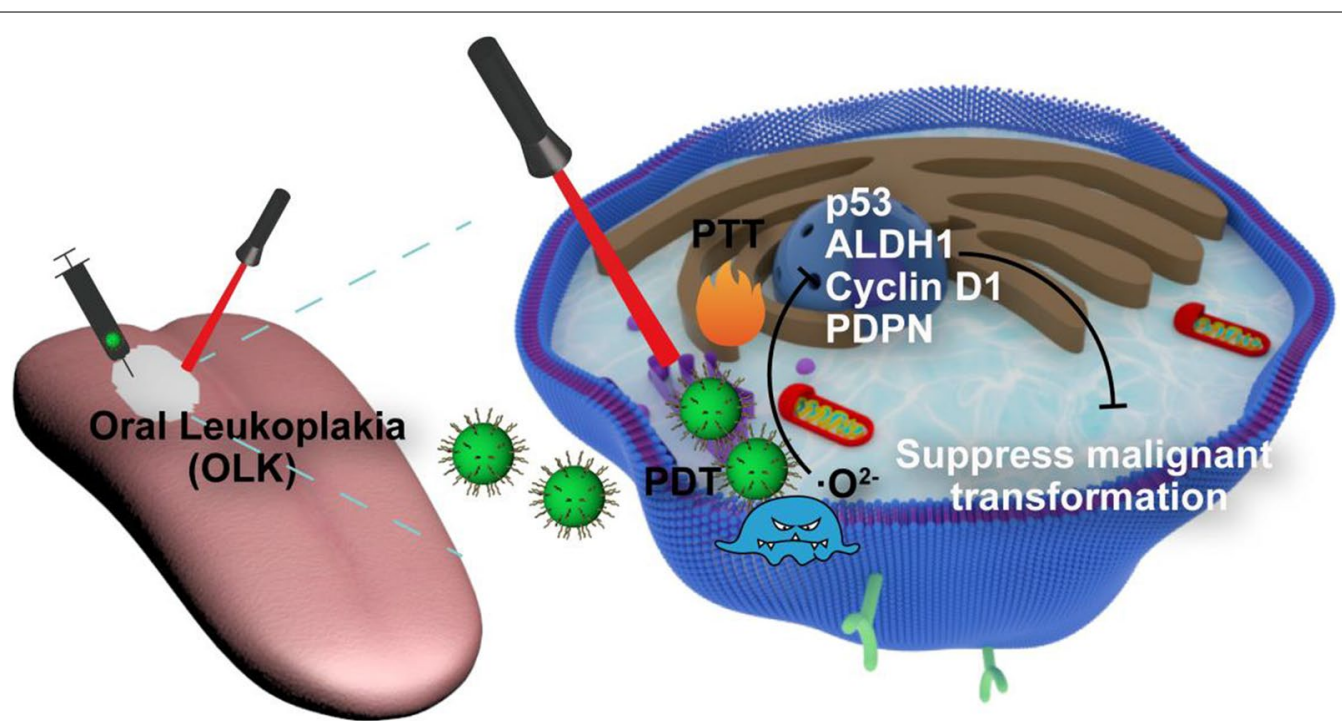

Fig. 6 The illustration of the synergistic PDT/PTT of ITIC-Th NPs after local injection in vivo 
temperature of the other four groups had hardly changed (Fig. 4D, E). The NPs can work with PDT and PTT, which owe better therapeutic effects than ALA.

All operations above were performed by the same operator, conducted every five days and each rat received three treatments. After treatment, clinical, histological, and biological indicators were assessed. During the next 14 days, changes in tongue lesions were monitored and recorded. Two experienced oral mucosal clinicians evaluated the therapeutic effect independently, and the particular method was described above. None of our cases had achieved complete clinical response $(\mathrm{CR}$, mean disappearance of all measurable disease). We speculated this was due to the continuous accumulation of $4 \mathrm{NQO}$ in the body $[59,60]$. The dysplasia continued to worsen even though the 4NQO drinking water was switched back to purified water. This phenomenon could be verified in the blank control group (Table S2). The negative controls showed a faster oral leukoplakia cancerization rate, proving that only laser irradiation had no therapeutic effect. Otherwise, pure injection of ITIC-Th NPs showed limited cancerization inhibition, indicating a poor therapeutic effect of the NPs alone. According to meta-analysis, ALA-PDT's overall response rate (including complete and partial response) to OLK was estimated at $76.1 \%$ [10]. In our study, the therapeutic effect of ALAPDT was slightly better than that of the control group. In contrast, for the ITIC-Th NPs group with $660 \mathrm{~nm}$ laser irradiation, the progression of carcinogenesis was almost controlled, and in several cases, the degree of keratosis was reversed due to the combined PTT and PDT effects, which showed high inhibition efficiency compared to ALA-PDT only (Fig. 5A and C). Furthermore, the immunohistochemical studies of tongue oral leukoplakia sections also highly supported the anti-carcinogenesis effects of various treatments, consistent with in vitro studies (Fig. 5B and D). The highest expression of ALDH1 and p53 was observed in the control group. In contrast, after being treated with ITIC-Th NPs $+660 \mathrm{~nm}$ laser, ALDH1 and p53 expression were significantly down-regulated. Therefore, the ITIC-Th NPs held superior anti-carcinogenesis efficacy.

In addition to the medical effectiveness of phototherapy, the long-term safety of photosensitizer must be considered. The biotoxicity of drugs was crucial for future biomedical application, so we conducted the biocompatibility of ITIC-Th NPs with SD rats. There was no apparent damage to the nearby vital tissues (upper lip, low lip, mucosa, sublingual gland, submaxillary lymph node (LN), and cervical LN, Fig. 5E), indicating the excellent biosafety of NPs. After intralesional injection of ITIC-Th NPs and laser irradiation, the body weight was recorded every other day. Each group did not have meaningful weight changes during the treatment (Fig. 5F). Major organs (heart, liver, spleen, lung, and kidney) were collected for H\&E staining, and no noticeable pathological changes were observed (Fig. 5G). Blood samples were obtained from the eyes of SD rats. The results of blood routine, liver function, and kidney function indexes showed no differences among the groups, suggesting the safety of this therapy (Fig. 5H-M). Given all the evidence above, the ITIC-Th NPs had superior biosafety and displayed an extraordinary capability against oral leukoplakia carcinogenesis.

To prevent the progression of the OPMDs to OSCC is critical to the treatment of OSCC. Local drug therapy, PDT, and surgical excision were the typical clinical therapy in the clinic, depending on different stages of OPMDs progression [14]. Local drug therapy with uncertain effects and an extended period, and the surgery is an invasive operation and full of terror to patients. The ALA-based PDT towards OLK owed the disadvantage of low response rate and complex process before and after the practice, which bring nonideal therapeutic effect and uncomfortable feeling [15]. To conquer the practical problems, our NPs with nanoscale can work with both PDT and PTT after laser illumination via local injection, which can shorten the course of treatment and reduce painfulness if injection with anesthetics. Also, compared with ALA, the NPs can easily enter cells and further influence cell metabolism [61]. Our study showed that the tumor-relative markers were altered to a normal stage in vitro and in vivo, which ultimately induced apoptosis of OLK cells and hindered malignant transformation progression. Huge amounts of research prove that the PTT-induced cells damage can release the damage-associated molecular patterns (DAMP) [62], which can initiate the immune response in tumor therapy. Though immunotherapy in OLK is rare, its development is viable and promising, bringing new sights and possibilities in OPMDs treatment (Fig. 6).

\section{Conclusions}

In summary, we successfully synthesized a novel organic photosensitizer ITIC-Th NPs with superior photodynamic/photothermal properties, excellent biosafety, strong anti-malignant transformation power, which was more convenient and efficient than traditional photosensitizers. The results were also exciting in premalignant animal models. As far as we know, this research was the first interdisciplinary study in the field of near-infrared fluorescence imaging and OLK. Our study provided a promising approach for photosensitizer in OLK's photodynamic and photothermal collaborative treatment, and it was of great benefit to block the canceration process of OLK, which has promising potential for future clinical treatment. 


\begin{abstract}
Abbreviations
OLK: Oral leukoplakia; PSs: Photosensitizers; PDT: Photodynamic therapy; ITIC-Th NPs: ITIC-Th nanoparticles; PTT: Photothermal therapy; ROS: Reactive oxygen species; 4NQO: 4-Nitroquinoline 1-oxide; OSCC: Oral squamous cell carcinoma; OPMDs: Oral potentially malignant disorders; WHO: World Health Organization; OLK: Oral leukoplakia; 5-ALA: 5-Aminolevulinic acid; PpIX: Porphyrin IX; NIR: Near-infrared; A-D-A: Acceptor-donor-acceptor; THF: Tetrahydrofuran; ATCC: American Type Culture Collection; SOSG: Singlet Oxygen Sensor Green; DPBF: 1, 3-Diphenylisobenzofuran; CCK-8: Cell Counting Kit-8: ALDH1: Aldehyde dehydrogenase isoform 1; PDCD5: Programmed cell death 5; PDPN: Podoplanin; TEM: Transmission electron microscope; DLS: Dynamic light scattering; K-SFM: Keratinocyte serum-free medium; HaCaT: Human immortalized keratinocyte line; DMEM: Dulbecco's modified Eagle's medium; FBS: Fetal Bovine Serum; DCFH-DA: 2, 7-Dichlorodi-hydrofluorescein diacetate; SD: Sprague-Dawley; H\&E: Hematoxylin and eosin; EDS: Energy-dispersive spectroscopy; ESR: Electron spin resonance; HNSCC: Head and neck squamous cell carcinoma; CDK: Cyclin-dependent kinase; CR: Complete clinical response; LN: Lymph node.
\end{abstract}

\section{Supplementary Information}

The online version contains supplementary material available at https://doi. org/10.1186/s12951-022-01310-2.

Additional file 1. Table S1. Clinic-pathological features of 10 patients with oral leukoplakia. Table S2. Histopathological examination results of each group after PTT / PDT.Figure S1. A The appearance of ITIC-Th NPS in different media at room temperature after two weeks. The DLS B and UV-VIS spectrum $\mathbf{C}$ of NPs in $\mathrm{pH} 7.0$ and pH 6.5. Figure S2. A Temperature change curves of ITIC-Th NPs solution ([ITIC-Th NPS] $=75 \mu \mathrm{g} / \mathrm{mL}$ ) under $660 \mathrm{~nm}$ laser irradiation. B The time constant for heat transfer was determined to be $\tau \mathbf{S}=232 \mathrm{~s}$. $\mathbf{C}$ The electron spin resonance (ESR) result of NPs. Figure S3. A The scheme of the experiment. B The near-infrared fluorescence imaging of NPs solution under different thickness covers of beef. Figure S4.A-C The cell activity assay of HaCaT, RAW264.7, and THP-1 with different concentrations of ITIC-Th NPS solutions evaluated by CCK-8. (D) Leuk-1 cells treated with hematoporphyrin for $24 \mathrm{~h}$, with or without laser. Figure S5. The ITIC-Th NPs with fluorescence in Leuk-1 and tumor cells (CAL 27) with different incubation times. Scale bar:100 $\mu \mathrm{m}$. Figure S6.A The quantitative analysis of Live/Dead cells stain in Figure 4D. ${ }^{* * *} \mathrm{p}$ $<0.001$. B The quantitative analysis of Figure 4E. ${ }^{* *} p<0.01$. Figure S7. A Expression of biomarkers in representative OLK tissues was detected by immunohistochemistry (Scale bar $=100 \mu \mathrm{m}$ ). B Quantitative analysis of Fig A. $\left(n=5\right.$, mean $\left.\pm S D,{ }^{*} p<0.05,{ }^{* *} p<0.01\right)$. C The negative control without primary antibodies (Scale bar $=100 \mu \mathrm{m}$ ). Figure S8. PDT/PTT Schematic illustration of treatment in rats.

\section{Acknowledgements}

The authors are grateful to Dr. Ning Duan for helping with the efficacy evaluation of animal experiments. And thanks to Mr. Lei Zhang and Mr. Sheng Chen for their generous help in preparing histopathological sections and immunohistochemical staining scores.

\section{Authors' contributions}

LL: Conceptualization, Data curation, Methodology, Writing —original draft preparation CS: Validation, Software, Methodology, Writing-original draft preparation ZW: Funding acquisition, Visualization HZ: Validation, Visualization ZC: Methodology, Visualization XZ: Formal analysis SH: Investigation, Visualization, Funding acquisition GZ: Investigation, Visualization JR: Investigation Yu Cai: Conceptualization, Project administration, Supervision, Writing-review \& editing, Funding acquisition WH: Conceptualization, Resources, Supervision, Writing - review \& editing, Funding acquisition. The manuscript was written through contributions of all authors. All authors read and approved the final manuscript.

\section{Funding}

This work was supported by the National Natural Science Foundation of China (82002864), the Natural Science Foundation of Jiangsu Province (BK20191121, BK20210033), the Natural Science Foundation of Zhejiang
Province (LQ22F050010), the Project of Invigorating Health Care through Science, Technology, and Education Jiangsu Provincial Medical Youth Talent (QNRC2016121), the China Postdoctoral Science Foundation (2021TQ0145), and the Nanjing Clinical Research Center for Oral Diseases (2019060009).

\section{Availability of data and materials}

All data generated or analysed during this study are included in this published article.

\section{Declarations}

Ethics approval and consent to participate

This study was approved by the Nanjing Stomatological Hospital Ethics Committee (Application Permit Number: 2019NL-029(KS)).

\section{Consent for publication}

Not applicable.

\section{Competing interests}

The authors declare that they have no competing interests.

\section{Author details}

${ }^{1}$ Department of Oral Medicine, Nanjing Stomatological Hospital, Medical School of Nanjing University, 30 Zhongyang Road, Nanjing 210008, China. ${ }^{2}$ Department of Oral and Maxillofacial Surgery, Nanjing Stomatological Hospital, Medical School of Nanjing University, No 30 Zhongyang Road, Nanjing 210008, China. ${ }^{3}$ Center for Rehabilitation Medicine, Rehabilitation \& Sports Medicine Research Institute of Zhejiang Province, Department of Rehabilitation Medicine, Zhejiang Provincial People's Hospital (Affiliated People's Hospital, Hangzhou Medical College), Hangzhou 310014, Zhejiang, China. ${ }^{4}$ Central Laboratory of Stomatology, Nanjing Stomatological Hospital, Medical School of Nanjing University, No 30 Zhongyang Road, Nanjing 210008, China. ${ }^{5}$ Institute of Translational Medicine, The Affiliated Drum Tower Hospital of Nanjing University Medical School, Nanjing 210008, China. ${ }^{6}$ Pediatric Dentistry, Nanjing Stomatology Hospital, Medical School of Nanjing University, No 30 Zhongyang road, Nanjing 210008, China.

Received: 29 November 2021 Accepted: 14 February 2022 Published online: 04 March 2022

\section{References}

1. Piyarathne NS, Rasnayake R, Angammana R, Chandrasekera P, Ramachandra S, Weerasekera M, Yasawardene S, Abu-Eid R, Jayasinghe JAP, Gupta E. Diagnostic salivary biomarkers in oral cancer and oral potentially malignant disorders and their relationships to risk factors - a systematic review. Expert Rev Mol Diagn. 2021. https://doi.org/10.1080/14737159. 2021.1944106.

2. Conway DI, Purkayastha M, Chestnutt IG. The changing epidemiology of oral cancer: definitions, trends, and risk factors. Br Dent J. 2018;225(9):867-73. https://doi.org/10.1038/sj.bdj.2018.922.

3. van der Waal I, Axéll T. Oral leukoplakia: a proposal for uniform reporting. Oral Oncol. 2002;38(6):521-6. https://doi.org/10.1016/s1368-8375(01) 00125-7.

4. van der Waal I. Historical perspective and nomenclature of potentially malignant or potentially premalignant oral epithelial lesions with emphasis on leukoplakia-some suggestions for modifications. Oral Surg Oral Med Oral Pathol Oral Radiol. 2018;125(6):577-81. https://doi.org/10. 1016/j.oooo.2017.11.023.

5. Warnakulasuriya S. Oral potentially malignant disorders: A comprehensive review on clinical aspects and management. Oral Oncol. 2020;102: 104550. https://doi.org/10.1016/j.oraloncology.2019.104550.

6. Johnson DE, Burtness B, Leemans CR, Lui VWY, Bauman JE, Grandis JR. Head and neck squamous cell carcinoma. Nat Rev Dis Primers. 2020;6(1):92. https://doi.org/10.1038/s41572-020-00224-3.

7. locca O, Sollecito TP, Alawi F, Weinstein GS, Newman JG, De Virgilio A, Di Maio P, Spriano G, Pardinas Lopez S, Shanti RM. Potentially malignant disorders of the oral cavity and oral dysplasia: a systematic review and 
meta-analysis of malignant transformation rate by subtype. Head Neck. 2020;42(3):539-55. https://doi.org/10.1002/hed.26006.

8. Kumar A, Cascarini L, McCaul JA, Kerawala CJ, Coombes D, Godden D, Brennan PA. How should we manage oral leukoplakia? Br J Oral Maxillofac Surg. 2013;51(5):377-83. https://doi.org/10.1016/j.bjoms.2012.10.018.

9. Brothwell DJ, Lewis DW, Bradley G, Leong I, Jordan RC, Mock D, Leake JL. Observer agreement in the grading of oral epithelial dysplasia. Community Dent Oral Epidemiol. 2003;31(4):300-5. https://doi.org/10.1034/j. 1600-0528.2003.00013.x.

10. Saini R, Poh CF. Photodynamic therapy: a review and its prospective role in the management of oral potentially malignant disorders. Oral Dis. 2013;19(5):440-51. https://doi.org/10.1111/odi.12003.

11. Li Y, Wang B, Zheng S, He Y. Photodynamic therapy in the treatment of oral leukoplakia: A systematic review. Photodiagnosis Photodyn Ther. 2019;25:17-22. https://doi.org/10.1016/j.pdpdt.2018.10.023.

12. Shafirstein G, Friedman A, Siegel E, Moreno M, Baumler W, Fan CY, Morehead K, Vural E, Stack BC, Jr., Suen, J. Y... Using 5-aminolevulinic acid and pulsed dye laser for photodynamic treatment of oral leukoplakia. Arch Otolaryngol Head Neck Surg. 2011;137(11):1117-23. https://doi.org/10. 1001/archoto.2011.178.

13. Wong SJ, Campbell B, Massey B, Lynch DP, Cohen EEW, Blair E, Selle R, Shklovskaya J, Jovanovic BD, Skripkauskas S, Dew A, Kulesza P, Parimi V, Bergan RC, Szabo E. A phase I trial of aminolevulinic acid-photodynamic therapy for treatment of oral leukoplakia. Oral Oncol. 2013;49(9):970-6. https://doi.org/10.1016/j.oraloncology.2013.05.011.

14. Chen Q, Dan H, Tang F, Wang J, Li X, Cheng J, Zhao H, Zeng X. Photodynamic therapy guidelines for the management of oral leucoplakia. Int J Oral Sci. 2019;11(2):14. https://doi.org/10.1038/s41368-019-0047-0.

15. Han Y, Xu S, Jin J, Wang X, Liu X, Hua H, Wang X, Liu H. Primary clinical evaluation of photodynamic therapy with oral leukoplakia in chinese patients. Front Physiol. 1911;2018:9. https://doi.org/10.3389/fphys.2018. 01911.

16. Yao Y, Shen $X$, Shi L, Tang G, Wu L. The combination of photodynamic therapy and fractional $\mathrm{CO} 2$ laser for oral leukoplakia: case series. Photodiagnosis Photodyn Ther. 2020;29: 101597. https://doi.org/10.1016/j.pdpdt. 2019.101597.

17. Pietruska M, Sobaniec S, Bernaczyk P, Cholewa M, Pietruski JK, Dolinska E, Skurska A, Duraj E, Tokajuk G. Clinical evaluation of photodynamic therapy efficacy in the treatment of oral leukoplakia. Photodiagnosis Photodyn Ther. 2014;11(1):34-40. https://doi.org/10.1016/j.pdpdt.2013. 10.003.

18. Jerjes W, Upile T, Hamdoon Z, Mosse CA, Akram S, Hopper C. Photodynamic therapy outcome for oral dysplasia. Lasers Surg Med. 2011;43(3):192-9. https://doi.org/10.1002//sm.21036.

19. Zhang X, Chen G, Liu Y, Sun L, Sun L, Zhao Y. Black phosphorus-loaded separable microneedles as responsive oxygen delivery carriers for wound healing. ACS Nano. 2020;14(5):5901-8. https://doi.org/10.1021/acsnano. 0c01059.

20. Yang N, Guo H, Cao C, Wang X, Song X, Wang W, Yang D, Xi L, Mou X, Dong $X$. Infection microenvironment-activated nanoparticles for NIR-II photoacoustic imaging-guided photothermal/chemodynamic synergistic anti-infective therapy. Biomaterials. 2021;275: 120918. https://doi.org/ 10.1016/j.biomaterials.2021.120918.

21. Wei Z, Zou H, Liu G, Song C, Tang C, Chen S, Zhang G, Ran J, Wang Y, Yin $X$, Cai Y, Han W. Peroxidase-mimicking evodiamine/indocyanine green nanoliposomes for multimodal imaging-guided theranostics for oral squamous cell carcinoma. Bioact Mater. 2021;6(7):2144-57. https://doi. org/10.1016/j.bioactmat.2020.12.016.

22. An F, Chen N, Conlon WJ, Hachey JS, Xin J, Aras O, Rodriguez EA, Ting R. Small ultra-red fluorescent protein nanoparticles as exogenous probes for noninvasive tumor imaging in vivo. Int J Biol Macromol. 2020;153:1006. https://doi.org/10.1016/j.ijbiomac.2020.02.253.

23. Olek M, Machorowska-Pieniążek A, Olek K, Cieślar G, Kawczyk-Krupka A. Photodynamic therapy in the treatment of oral squamous cell carcinoma - The state of the art in preclinical research on the animal model. Photodiagnosis Photodyn Ther. 2021;34: 102236. https://doi.org/10.1016/.pdpdt. 2021.102236.

24. Dickerson EB, Dreaden EC, Huang X, El-Sayed IH, Chu H, Pushpanketh $\mathrm{S}$, McDonald JF, El-Sayed MA. Gold nanorod assisted near-infrared plasmonic photothermal therapy (PPTT) of squamous cell carcinoma in mice.
Cancer Lett. 2008;269(1):57-66. https://doi.org/10.1016/j.canlet.2008.04. 026.

25. Hou X, Tao Y, Pang Y, Li X, Jiang G, Liu Y. Nanoparticle-based photothermal and photodynamic immunotherapy for tumor treatment. Int J Cancer. 2018;143(12):3050-60. https://doi.org/10.1002/ijc.31717.

26. Yu JE, Jeon SJ, Choi JY, Han YW, Ko EJ, Moon DK. A 3-fluoro-4-hexylthiophene-based wide bandgap donor polymer for 109\% efficiency eco-friendly nonfullerene organic solar cells. Small. 2019;15(9):e1805321. https://doi.org/10.1002/smll.201805321.

27. Lin Y, Zhao F, He Q, Huo L, Wu Y, Parker TC, Ma W, Sun Y, Wang C, Zhu D, Heeger AJ, Marder SR, Zhan X. High-performance electron acceptor with thienyl side chains for organic photovoltaics. J Am Chem Soc. 2016;138(14):4955-61. https://doi.org/10.1021/jacs.6b02004.

28. Song C, Ran J, Wei Z, Wang Y, Chen S, Lin L, Zhang G, Cai Y, Han W. Organic near-infrared-II nanophotosensitizer for safe cancer phototheranostics and improving immune microenvironment against metastatic tumor. ACS Appl Mater Interfaces. 2021;13(3):3547-58. https://doi.org/10. 1021/acsami.0c18841.

29. Zhang J, Yang C, Zhang R, Chen R, Zhang Z, Zhang W, Peng SH, Chen X, Liu G, Hsu CS, Lee CS. Biocompatible D-A semiconducting polymer nanoparticle with light-harvesting unit for highly effective photoacoustic imaging guided photothermal therapy. Adv Funct Mater. 2017;27(13):1605094. https://doi.org/10.1002/adfm.201605094.

30. Nagao T, Warnakulasuriya S, Nakamura T, Kato S, Yamamoto K, Fukano H, Suzuki K, Shimozato K, Hashimoto S. Treatment of oral leukoplakia with a low-dose of beta-carotene and vitamin C supplements: a randomized controlled trial. Int J Cancer. 2015;136(7):1708-17. https://doi.org/10. 1002/ijc.29156.

31. Yu CH, Chen HM, Hung HY, Cheng SJ, Tsai T, Chiang CP. Photodynamic therapy outcome for oral verrucous hyperplasia depends on the clinical appearance, size, color, epithelial dysplasia, and surface keratin thickness of the lesion. Oral Oncol. 2008;44(6):595-600. https://doi.org/10.1016/j. oraloncology.2007.08.016.

32. Cai Y, Liang P, Tang Q, Yang X, Si W, Huang W, Zhang Q, Dong X. Diketopyrrolopyrrole-triphenylamine organic nanoparticles as multifunctional reagents for photoacoustic imaging-guided photodynamic/photothermal synergistic tumor therapy. ACS Nano. 2017;11(1):1054-63. https://doi. org/10.1021/acsnano.6b07927.

33. Zhao B, Wang Y, Yao X, Chen D, Fan M, Jin Z, He Q. Photocatalysismediated drug-free sustainable cancer therapy using nanocatalyst. Nat Commun. 2021;12(1):1345. https://doi.org/10.1038/s41467-021-21618-1.

34. Cai Y, Wei Z, Song C, Tang C, Han W, Dong X. Optical nano-agents in the second near-infrared window for biomedical applications. Chem Soc Rev. 2019:48(1):22-37. https://doi.org/10.1039/c8cs00494c.

35. Cai X, Wang KN, Ma W, Yang Y, Chen G, Fu H, Cui C, Yu Z, Wang X. Multifunctional AIE iridium (III) photosensitizer nanoparticles for twophoton-activated imaging and mitochondria targeting photodynamic therapy. J Nanobiotechnology. 2021;19(1):254. https://doi.org/10.1186/ s12951-021-01001-4.

36. Zhang Q, Guo Q, Chen Q, Zhao X, Pennycook SJ, Chen H. Highly efficient 2D NIR-II photothermal agent with fenton catalytic activity for cancer synergistic photothermal-chemodynamic therapy. Advanced Science. 2020. https://doi.org/10.1002/advs.201902576.

37. Atchison J, Kamila S, Nesbitt H, Logan KA, Nicholas DM, Fowley C, Davis J, Callan B, McHale AP, Callan JF. lodinated cyanine dyes: a new class of sensitisers for use in NIR activated photodynamic therapy (PDT). Chem Commun (Camb). 2017;53(12):2009-12. https://doi.org/10.1039/c6cc0 $9624 \mathrm{~g}$.

38. Zhang X, Cheng L, Lu Y, Tang J, Lv Q, Chen X, Chen Y, Liu J. A mxene-based bionic cascaded-enzyme nanoreactor for tumor phototherapy/enzyme dynamic therapy and hypoxia-activated chemotherapy. Nanomicro Lett. 2021;14(1):22. https://doi.org/10.1007/s40820-021-00761-w.

39. Panieri E, Santoro MM. ROS homeostasis and metabolism: a dangerous liason in cancer cells. Cell Death Dis. 2016;7(6): e2253. https://doi.org/10. 1038/cddis.2016.105.

40. Zou H, Wei Z, Song C, Ran J, Cao Z, Tang C, Zhang G, Cai Y, Lu M, Han W. Novel NIR-II semiconducting molecule incorporating sorafenib for imaging guided synergetic cancer phototherapy and anti-angiogenic therapy. J Mater Chem B. 2021;9(14):3235-48. https://doi.org/10.1039/d1tb0 0209k. 
41. Liu J, Fu M, Miao J, Sun Y, Zhu R, Liu C, Bi R, Wang S, Cao X. The toxicity of cooking oil fumes on human bronchial epithelial cells through ROSmediated MAPK, NF-KB signaling pathways and NLRP3 inflammasome. Environ Toxicol. 2022. https://doi.org/10.1002/tox.23465.

42. Song C, Xu W, Wei Z, Ou C, Wu J, Tong J, Cai Y, Dong X, Han W. AntiLDLR modified TPZ@Ce6-PEG complexes for tumor hypoxia-targeting chemo-/radio-/photodynamic/photothermal therapy. J Mater Chem B. 2020;8(4):648-54. https://doi.org/10.1039/c9tb02248a.

43. Das D, Maitra A, Panda CK, Ghose S, Roy B, Sarin R, Majumder PP. Genes and pathways monotonically dysregulated during progression from normal through leukoplakia to gingivo-buccal oral cancer. NPJ Genom Med. 2021;6(1):32. https://doi.org/10.1038/s41525-021-00195-8.

44. Kawaguchi H, El-Naggar AK, Papadimitrakopoulou V, Ren H, Fan YH, Feng L, Lee JJ, Kim E, Hong WK, Lippman SM, Mao L. Podoplanin: a novel marker for oral cancer risk in patients with oral premalignancy. J Clin Oncol. 2008;26(3):354-60. https://doi.org/10.1200/jco.2007.13.4072.

45. Liu W, Wu L, Shen XM, Shi LJ, Zhang CP, Xu LQ, Zhou ZT. Expression patterns of cancer stem cell markers ALDH1 and CD133 correlate with a high risk of malignant transformation of oral leukoplakia. Int J Cancer. 2013;132(4):868-74. https://doi.org/10.1002/ijc.27720.

46. Habiba U, Hida K, Kitamura T, Matsuda AY, Higashino F, Ito YM, Ohiro Y, Totsuka Y, Shindoh M. ALDH1 and podoplanin expression patterns predict the risk of malignant transformation in oral leukoplakia. Oncol Lett. 2017;13(1):321-8. https://doi.org/10.3892/ol.2016.5379.

47. Li Y, Li LJ, Zhang ST, Wang LJ, Zhang Z, Gao N, Zhang YY, Chen QM. In vitro and clinical studies of gene therapy with recombinant human adenovirus-p53 injection for oral leukoplakia. Clin Cancer Res. 2009;15(21):672431. https://doi.org/10.1158/1078-0432.CCR-09-1296.

48. Kujan O, Huang G, Ravindran A, Vijayan M, Farah CS. CDK4, CDK6, cyclin D1 and Notch 1 immunocytochemical expression of oral brush liquidbased cytology for the diagnosis of oral leukoplakia and oral cancer. J Oral Pathol Med. 2019;48(7):566-73. https://doi.org/10.1111/jop.12902.

49. Kwak S, Lee S-H, Han E-J, Park S-Y, Jeong M-H, Seo J, Park S-H, Sung G-J, Yoo J-Y, Yoon H-G, Choi K-C. Serine/threonine kinase 31 promotes PDCD5-mediated apoptosis in p53-dependent human colon cancer cells. J Cell Physiol. 2019;234(3):2649-58. https://doi.org/10.1002/jcp.27079.

50. Xu F, Wu K, Zhao M, Qin Y, Xia M. Expression and clinical significance of the programmed cell death 5 gene and protein in laryngeal squamous cell carcinoma. J Int Med Res. 2013;41(6):1838-47. https://doi.org/10. 1177/0300060513498021.

51. Monteiro L, Mello FW, Warnakulasuriya S. Tissue biomarkers for predicting the risk of oral cancer in patients diagnosed with oral leukoplakia: a systematic review. Oral Dis. 2020. https://doi.org/10.1111/odi.13747.

52. Warnakulasuriya S, Ariyawardana A. Malignant transformation of oral leukoplakia: a systematic review of observational studies. J Oral Pathol Med. 2016;45(3):155-66. https://doi.org/10.1111/jop.12339.

53. Li Q, Dong H, Yang G, Song Y, Mou Y, Ni Y. Mouse tumor-bearing models as preclinical study platforms for oral squamous cell carcinoma. Front Oncol. 2020;10:212. https://doi.org/10.3389/fonc.2020.00212.

54. Barcessat AR, Huang I, Rabelo GD, Rosin FC, Ferreira LG, de Cerqueira Luz JG, Correa L. Systemic toxic effects during early phases of topical 4-NQOinduced oral carcinogenesis in rats. J Oral Pathol Med. 2014;43(10):770-7. https://doi.org/10.1111/jop.12190.

55. Vered M, Yarom N, Dayan D. 4NQO oral carcinogenesis: animal models, molecular markers and future expectations. Oral Oncol. 2005;41(4):337-9. https://doi.org/10.1016/j.oraloncology.2004.07.005.

56. Ludwig S, Hong C-S, Razzo BM, Fabian KPL, Chelvanambi M, Lang S, Storkus WJ, Whiteside TL. Impact of combination immunochemotherapies on progression of $4 \mathrm{NQO}$-induced murine oral squamous cell carcinoma. Cancer Immunol Immunother. 2019;68(7):1133-41. https:// doi.org/10.1007/s00262-019-02348-2.

57. Kong X, Yang X, Zhou J, Chen S, Li X, Jian F, Deng P, Li W. Analysis of plasma metabolic biomarkers in the development of 4-nitroquinoline1-oxide-induced oral carcinogenesis in rats. Oncol Lett. 2015;9(1):283-9. https://doi.org/10.3892/ol.2014.2619.

58. Gumus R, Capik O, Gundogdu B, Tatar A, Altinkaynak K, Ozdemir Tozlu O, Karatas OF. Low Vitamin D and High Cholesterol facilitate oral carcinogenesis in 4NQO induced rat models via regulating glycolysis. Oral Dis. 2021. https://doi.org/10.1111/odi.14117.

59. Wen L, Lu H, Li Q, Li Q, Wen S, Wang D, Wang X, Fang J, Cui J, Cheng B, Wang Z. Contributions of $T$ cell dysfunction to the resistance against
anti-PD-1 therapy in oral carcinogenesis. J Exp Clin Cancer Res. 2019;38(1):299. https://doi.org/10.1186/s13046-019-1185-0.

60. Oghumu S, Knobloch TJ, Terrazas C, Varikuti S, Ahn-Jarvis J, Bollinger CE, Iwenofu H, Weghorst CM, Satoskar AR. Deletion of macrophage migration inhibitory factor inhibits murine oral carcinogenesis: potential role for chronic pro-inflammatory immune mediators. Int J Cancer. 2016;139(6):1379-90. https://doi.org/10.1002/ijc.30177.

61. Wang J, Wang K, Liang J, Jin J, Wang X, Yan S. Chitosan-tripolyphosphate nanoparticles-mediated co-delivery of MTHFD1L shRNA and 5-aminolevulinic acid for combination photodynamic-gene therapy in oral cancer. Photodiagnosis Photodyn Ther. 2021;36: 102581. https://doi.org/10. 1016/j.pdpdt.2021.102581.

62. Xuan Y, Guan M, Zhang S. Tumor immunotherapy and multi-mode therapies mediated by medical imaging of nanoprobes. Theranostics. 2021;11(15):7360-78. https://doi.org/10.7150/thno.58413.

\section{Publisher's Note}

Springer Nature remains neutral with regard to jurisdictional claims in published maps and institutional affiliations.

Ready to submit your research? Choose BMC and benefit from:

- fast, convenient online submission

- thorough peer review by experienced researchers in your field

- rapid publication on acceptance

- support for research data, including large and complex data types

- gold Open Access which fosters wider collaboration and increased citations

- maximum visibility for your research: over $100 \mathrm{M}$ website views per year

At BMC, research is always in progress.

Learn more biomedcentral.com/submissions 